QA: QA

TDR-EBS-MD-000008 REV 01

March 2001

\title{
Waste Package Design Sensitivity Report
}

by

Pierre Macheret

Prepared for:

U.S. Department of Energy

Yucca Mountain Site Characterization Office

P.O. Box 30307

North Las Vegas, Nevada 89036-0307

Prepared by:

Bechtel SAIC Company, LLC

1180 Town Center Drive

Las Vegas, Nevada 89144

Under Contract Number

DE-AC08-01NV12101 


\section{DISCLAIMER}

This report was prepared as an account of work sponsored by an agency of the United States Government. Neither the United States Government nor any agency thereof, nor any of their employees, nor any of their contractors, subcontractors or their employees, makes any warranty, express or implied, or assumes any legal liability or responsibility for the accuracy, completeness, or any third party's use or the results of such use of any information, apparatus, product, or process disclosed, or represents that its use would not infringe privately owned rights. Reference herein to any specific commercial product, process, or service by trade name, trademark, manufacturer, or otherwise, does not necessarily constitute or imply its endorsement, recommendation, or favoring by the United States Government or any agency thereof or its contractors or subcontractors. The views and opinions of authors expressed herein do no necessarily state or reflect those of the United States Government or any agency thereof. 
Bechtel SAIC Company, LLC

Waste Package Design Sensitivity Report

TDR-EBS-MD-000008 REV 01

March 2001

Prepared by:

P. Macht:

Pierre Macheret

Waste Package Project

Checked by:

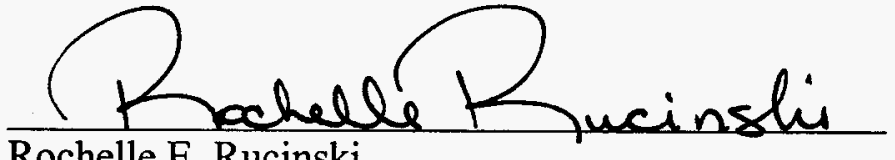

Rochelle E. Rucinski

Waste Package Project

Approved by:

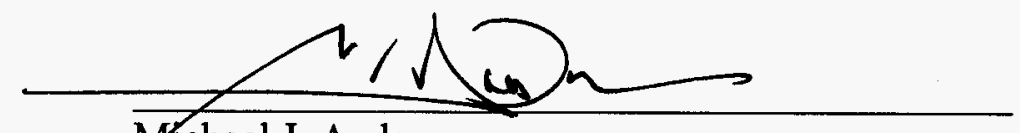

Michael J. Anderson

Waste Package Project

Manager, Waste Package Design Section
$03 / 08 / 2001$

Date
$03 / 08 / 2001$

Date
$3 / 961$

Date 


\section{REVISION RECORD}

Revision Number

00

01

\section{Description of Change}

Initial issue.

Revision to update the technical report in the light of the work performed by the Waste Package Project for Site Recommendation. Besides, the report reflects the changes due to the revision of the system description documents. Deeper insight of the work to be performed for License Application is also provided. Finally, numerous editorial corrections are done. The changes made are identified by change bars in the left margin of the document. 


\section{CONTENTS}

Page

ACRONYMS AND ABBREVIATIONS viii

1. OBJECTIVE AND SCOPE. 1

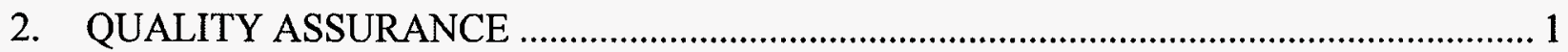

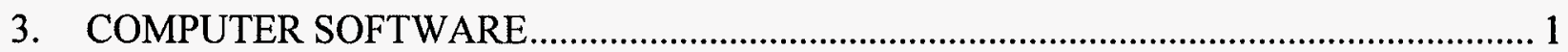

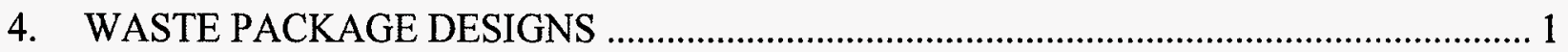

4.1 COMMERCIAL SPENT NUCLEAR FUEL ......................................................... 2

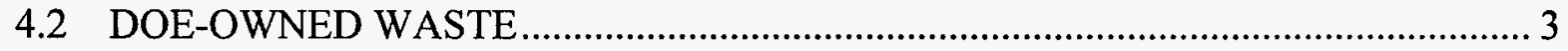

4.3 NAVAL SPENT NUCLEAR FUEL ................................................................. 4

5. DETERMINATION OF DESIGNS TO BE EVALUATED FOR THE SITE RECOMMENDATION ..................................................................................... 4

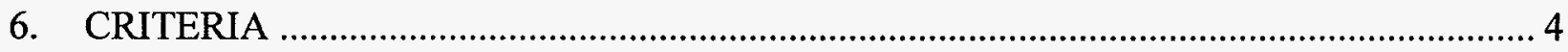

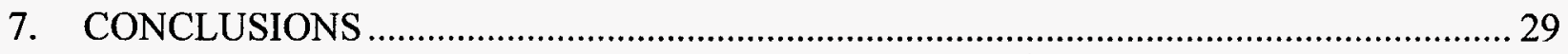

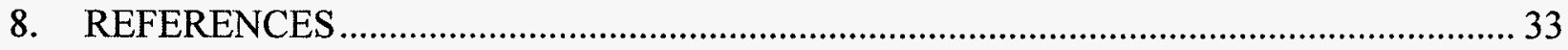

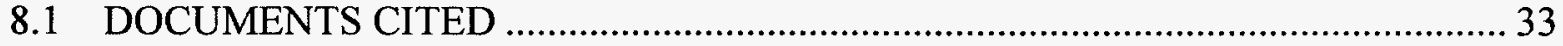

8.2 CODES, STANDARDS, REGULATIONS, AND PROCEDURES ...................... 36

APPENDIX A - DETERMINATION OF CODISPOSAL CONFIGURATIONS.................... A-1 


\section{TABLES}

Page

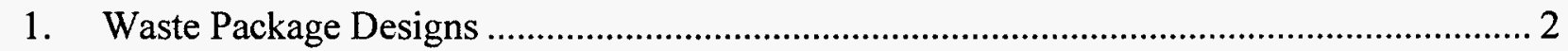

2. UCF, DHLW, and Naval System Description Document Criteria ......................................... 6

3. Emplacement Drift System Description Document Criteria .................................................. 22

4. Structural System Description Document Criteria Addressed for SR ................................... 30

5. Thermal System Description Document Criteria Addessed for SR ....................................... 31

6. Shielding System Description Document Criteria Addressed for SR …............................. 32

7. Criticality System Description Document Criteria Addressed for SR .................................. 32

8. System Description Document Criteria to be Addressed for LA-CA.......................................32

9. System Description Document Criteria to be Addressed for LA-R\&P ................................. 33 


\section{ACRONYMS AND ABBREVIATIONS}

BWR boiling water reactor

CRWMS Civilian Radioactive Waste Management System

|

DHLW defense high-level waste

DOE U.S. Department of Energy

\begin{tabular}{|c|c|}
\hline LA & License Application \\
\hline LA-CA & License Application - Construction Authorization \\
\hline LA-R\&P & License Application - Receive \& Possess \\
\hline $\mathrm{M} \& \mathrm{O}$ & Management and Operating Contractor \\
\hline NRC & U.S. Nuclear Regulatory Commission \\
\hline PWR & pressurized water reactor \\
\hline SNF & spent nuclear fuel \\
\hline SR & Site Recommendation \\
\hline TBD & to be determined \\
\hline TBV & to be verified \\
\hline TSPA & total system performance assessment \\
\hline UCF & uncanistered commercial fuel \\
\hline WP & waste package \\
\hline
\end{tabular}




\section{OBJECTIVE AND SCOPE}

The purpose of this technical report is to present the current designs for waste packages and determine which designs will be evaluated for the Site Recommendation (SR) or Licence Application (LA), to demonstrate how the design will be shown to comply with the applicable design criteria. The evaluations to support SR or LA are based on system description document criteria. The objective is to determine those system description document criteria for which compliance is to be demonstrated for SR; and, having identified the criteria, to refer to the documents that show compliance. In addition, those system description document criteria for which compliance will be addressed for LA are identified, with a distinction made between two steps of the LA process: the LA-Construction Authorization (LA-CA) phase on one hand, and the LA-Receive and Possess (LA-R\&P) phase on the other hand. The scope of this work encompasses the Waste Package Project disciplines for criticality, shielding, structural, and thermal analysis.

\section{QUALITY ASSURANCE}

The Quality Assurance program applies to this technical report. All types of waste packages were classified (per QAP-2-3, Classification of Permanent Items) as Quality Level-1. Classification of the MGR Uncanistered Spent Nuclear Fuel Disposal Container System (CRWMS M\&O 1999c, p. 7) provides the classification for waste package designs that will contain uncanistered spent nuclear fuel assemblies. This classification analysis is applicable to all of the waste package designs included in the Monitored Geologic Repository Classification Analyses. The reference cited here merely serves as an example for waste package classification. The drip shields and support hardware (emplacement pallets) were classified (per QAP-2-3) as Quality Level-1 in Classification of the MGR Ex-Container System (CRWMS M\&O 1999b, p. 8). This technical report is conducted under Technical Work Plan for: Waste Package Design Description for LA (CRWMS M\&O 2000o, main body of the document and pp. 16 to 21 in Addendum A), developed in accordance with AP-3.11Q, Technical Reports, and is subject to the Quality Assurance Requirements and Description (DOE 2000) requirements. The control of the electronic management of data was accomplished in accordance with methods specified in the technical work plan (CRWMS M\&O 2000o, p. 45 in addendum B).

\section{COMPUTER SOFTWARE}

There is no computer software used in the preparation of this report.

\section{WASTE PACKAGE DESIGNS}

The current waste package designs are listed in Table 1. Sections 4.1 through 4.3 provide some background concerning the evolution of the waste package designs shown in Table 1. 
Table 1. Waste Package Designs

\begin{tabular}{|c|c|}
\hline Waste Package Design & General Loading Description \\
\hline 21-PWR ${ }^{b}$ Absorber Plate & $\begin{array}{l}\text { Designed to hold } 21 \text { commercial pressurized water reactor assemblies. } \\
\text { Absorber plates will be used for criticality control. }\end{array}$ \\
\hline 21-PWR Control Rod & $\begin{array}{l}\text { Designed to hold } 21 \text { commercial pressurized water reactor assemblies. } \\
\text { Control rods are placed in all assemblies to provide an additional } \\
\text { criticality control. }\end{array}$ \\
\hline 12-PWR Long & $\begin{array}{l}\text { Designed to hold } 12 \text { commercial pressurized water reactor assemblies. } \\
\text { Absorber plates will be used for criticality control. This design was } \\
\text { developed to hold longer pressurized water reactor assemblies. }\end{array}$ \\
\hline 44-BWR ${ }^{b}$ & $\begin{array}{l}\text { Designed to hold } 44 \text { commercial boiling water reactor assemblies. } \\
\text { Absorber plates will be used for criticality control. }\end{array}$ \\
\hline 24-BWR & $\begin{array}{l}\text { Designed to hold } 24 \text { commercial boiling water reactor assemblies. } \\
\text { Absorber plates thicker than those used in the 44-BWR design are used } \\
\text { to provide a higher level of criticality control. }\end{array}$ \\
\hline 5-DHLW ${ }^{b} /$ DOE SNF ${ }^{b}$ Short & $\begin{array}{l}\text { Designed to hold five short high-level waste canisters and one short U.S. } \\
\text { Department of Energy (DOE) spent nuclear fuel canister }{ }^{\mathrm{a}} \text {. This design } \\
\text { will also hold five high-level waste canisters containing immobilized } \\
\text { plutonium with no DOE spent nuclear fuel canister. }\end{array}$ \\
\hline 5-DHLW / DOE SNF Long & $\begin{array}{l}\text { Designed to hold five long high-level waste canisters and one long DOE } \\
\text { spent nuclear fuel canister. }\end{array}$ \\
\hline 2-MCO / 2-DHLW & $\begin{array}{l}\text { Designed to hold two DOE multi-canister overpacks and two long high- } \\
\text { level waste canisters. }\end{array}$ \\
\hline Naval SNF Short & Designed to hold one short naval spent nuclear fuel canister. \\
\hline Naval SNF Long & Designed to hold one long naval spent nuclear fuel canister. \\
\hline
\end{tabular}

NOTES: a High-level waste canisters disposed of in this waste package could be defense high-level waste or commercial high-level waste.

b PWR: pressurized water reactor, BWR: boiling water reactor, DHLW: defense high-level waste, SNF: spent nuclear fuel, MCO: multi-canister overpack.

\subsection{COMMERCIAL SPENT NUCLEAR FUEL}

Commercial spent nuclear fuel is expected to arrive in three forms: uncanistered (bare) pressurized water reactor or boiling water reactor assemblies; pressurized water reactor or boiling water reactor assemblies canistered in a non-disposable canister; and disposable canisters containing one failed assembly, portions of a failed assembly, or non-fuel components. The waste package designs developed to hold commercial waste can accommodate all three waste forms, provided that the disposable canisters are dimensionally compatible with the waste package basket openings.

Based on varying the capacity and criticality control methods for various waste package concepts, the Determination of Waste Package Configurations (CRWMS M\&O 1997, pp. 29-30) determined that the most economical solution was to use eight waste package designs to dispose of commercial waste. By introducing thermal blending for the LA Design Selection, the number of types of waste packages was reduced to seven (CRWMS M\&O 1999e, p. 10). As a defensein-depth measure that reduces the risk of a criticality event caused by a misload, this number has been further reduced to five types by eliminating the two designs that contained no neutronabsorbing material.

There is a limited amount of commercial high-level waste that will be treated the same as defense high-level waste. 


\subsection{DOE-OWNED WASTE}

DOE-owned waste is expected to arrive in six forms:

1. Short high-level waste canister

2. Short high-level waste canister containing immobilized plutonium

3. Long high-level waste canister

4. Short DOE spent nuclear fuel canister

5. Long DOE spent nuclear fuel canister

6. Multi-canister overpack containing N-reactor fuel

The DOE also owns a limited amount of commercial waste that will be handled in the same manner as the commercial waste stream.

It should be noted that for high-level waste, the typical matrix will be glass, however, there is a limited amount of high-level waste that is proposed to be disposed of with metal and ceramic matrices. The high-level waste canisters will be disposed of in a waste package configuration where a DOE spent nuclear fuel canister will be surrounded by five high-level waste canisters. Five short high-level waste canisters will be codisposed with one short DOE spent nuclear fuel canister. This waste package is referred to as the 5-DHLW/DOE SNF Short waste package. Five long high-level waste canisters will be codisposed with either a long DOE spent nuclear fuel canister or a short DOE spent nuclear fuel canister, depending on need. This waste package is referred to as the 5-DHLW/DOE SNF long waste package.

An additional waste form is planned to be constructed from surplus weapons plutonium, which will be immobilized in ceramic disks. These disks will be placed in sealed cans and disposed of in a standard high-level waste canister (can-in-canister). The Project currently shows that five of these immobilized-plutonium canisters can be placed in one waste package. This configuration does not allow a DOE spent nuclear fuel canister to be placed in the center location of the waste package (co-disposal). Further study will be done to evaluate the risk of criticality associated with this configuration. If deemed necessary for criticality control, the number of immobilizedplutonium canisters would be recommended. If the number of immobilized-plutonium canisters is greatly reduced per waste package, the option for co-disposal with DOE spent nuclear fuel will also be re-evaluated as this could reduce the total number of required waste packages.

For N-reactor spent nuclear fuel, the number of multi-canister overpacks per waste package is limited to two in order to reduce the risk of criticality. The limitation of disposing of only two multi-canister overpacks per waste package makes it desirable to codispose the multi-canister overpacks with high-level waste canisters because a waste package containing two canisters is an inefficient configuration. A brief cost study, presented in Appendix A, was performed to determine the most efficient method for disposing of the multi-canister overpacks with high-level waste canisters. The most efficient configuration is to dispose of two multi-canister overpacks with two long high-level waste canisters. This waste package is referred to as the 2-MCO/2DHLW waste package. 


\subsection{NAVAL SPENT NUCLEAR FUEL}

The Navy has proposed two disposable canisters for disposal of the naval spent nuclear fuel. Two waste package designs have been developed to dispose of these canisters, one canister per waste package. The naval spent nuclear fuel waste packages are identified by length; one is referred to as the Naval SNF short waste package, and the other is referred to as the Naval SNF long waste package.

\section{DETERMINATION OF DESIGNS TO BE EVALUATED FOR THE SITE RECOMMENDATION}

Section 4 presented the current list of waste package designs. Detailed and documented designs for each type of waste package are not developed for SR. Rather, the methodology used to develop and evaluate the designs will be demonstrated. This methodology will be demonstrated on representative designs from the list. It is desired to have a sampling that represents all of the types of waste packages.

For commercial fuel, there are two types of waste packages, the one designed to receive presurized water reactor spent nuclear fuel and the one designed to receive boiling water reactor spent nuclear fuel. The design methodology will be demonstrated on the most common designs for each of these types of packages, the 21-PWR absorber plate and the 44-BWR.

For DOE-owned waste and naval spent nuclear fuel, there are two general types of package, those containing multiple canisters and those containing a single canister. For the multiplecanister designs, the design methodology will be demonstrated on the waste package with the best defined waste form, the 5-DHLW/DOE SNF short. For the single-canister designs, the design methodology will be demonstrated on the naval spent nuclear fuel long waste package because it is the longest, heaviest waste package design. These two designs are representative of all of the DOE-owned waste and Naval spent nuclear fuel waste packages.

\section{CRITERIA}

This section lists all criteria from the system description documents that apply to the four designs selected in Section 5 to be used to support SR, LA-CA, or LA-R\&P. Because the scope of this work is limited to the Waste Package Project disciplines for criticality, shielding, structural, and thermal analysis, no criterion categorization according to SR, LA-CA, or LA-R\&P is provided when other organizations, such as Performance Assessment for example, are responsible for showing compliance.

Based on the design discipline categorization in this section, Section 7 lists for each discipline the system description document criteria addressed for SR, and refers to the documents that provide compliance demonstration. The other system description document criteria in support of LA-CA and LA-R\&P are listed also.

Criteria from the system description documents are listed by the system description document from which the criterion is taken, i.e., UCF (uncanistered commercial spent nuclear fuel 
[CRWMS M\&O 2000r]), DHLW (CRWMS M\&O 2000b), Naval (CRWMS M\&O 2000m), and Drift (CRWMS M\&O 20001), and the section in the system description document in which the criterion is found. When criteria from multiple system description documents are the same and are listed together, the wording, including table numbers, is taken from the first criterion listed. It should be noted that table references that are contained in the system description document criteria statements are not included in this report.

Table 2 lists all criteria from the UCF, DHLW and Naval system description documents. Table 3 lists all the criteria from the emplacement drift system description document. Criteria that are not applicable to this report are marked as not applicable (N/A) for SR or LA and justification is provided in the 'comments' column. 
Table 2. UCF, DHLW, and Naval System Description Document Criteria

\begin{tabular}{|c|c|c|c|c|c|c|c|c|c|}
\hline \multicolumn{3}{|c|}{$\begin{array}{c}\text { System Description Document } \\
\text { Criterion Number }\end{array}$} & \multirow[b]{2}{*}{ Criteria Description } & \multicolumn{4}{|c|}{ Design Discipline } & \multirow[b]{2}{*}{$\begin{array}{l}\text { Calculation } \\
\text { Reflecting } \\
\text { Design } \\
\text { Methodology } \\
\text { for SR or LA? }\end{array}$} & \multirow[b]{2}{*}{ Comments } \\
\hline UCF & DHLW & Naval & & 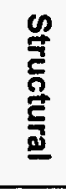 & 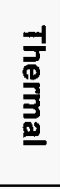 & $\frac{\text { ڤO) }}{\frac{\bar{\sigma}}{0}}$ & 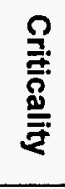 & & \\
\hline \multicolumn{10}{|c|}{ System Performance Criteria } \\
\hline 1.2.1.1 & $\mathrm{N} / \mathrm{A}$ & N/A & $\begin{array}{l}\text { "The disposal container shall accommodate intact fuel } \\
\text { assemblies from the assembly classes identified in } \\
\text { Tables } 1 \text { and } 2 \text { (TBV-455). Tables } 1 \text { and } 2 \text { also identify } \\
\text { parameters (size, weight, and inventory) that are } \\
\text { provided for information only. The reactors that } \\
\text { correspond to the multiple reactor classes (such as GE } \\
\text { BWR } 2,3 \text { assembly class) are listed in Appendix F for } \\
\text { reference (TBV-455). TBV-455 is placed on this } \\
\text { criterion because that TBV is placed on the reference } \\
\text { documents, in accordance with 'Deficiency Report } \\
\text { VAMO-98-D-132'." }\end{array}$ & $\mathrm{x}$ & & & & SR & \\
\hline N/A & 1.2.1.1 & N/A & $\begin{array}{l}\text { "The disposal container shall accommodate the HLW } \\
\text { canisters identified in Table } 1 . \text { Table } 1 \text { also identifies } \\
\text { nominal parameters (size, weight, and materials) that } \\
\text { may be used in design (TBV-264). (TBV-455 is also } \\
\text { placed on this criterion because that TBV is placed on } \\
\text { the reference document, in accordance with 'Deficiency } \\
\text { Report VAMO-98-D-132.')" }\end{array}$ & $\mathrm{X}$ & & & & SR & \\
\hline 1.2.1.2 & N/A & N/A & $\begin{array}{l}\text { "The disposal container shall accommodate sealed, } \\
\text { disposable, single-element SNF canisters (canisters } \\
\text { containing non-intact fuel that will not be opened and } \\
\text { repackaged in the surface facilities) that are capable of } \\
\text { fitting without forcing (when lowered vertically) into a } \\
\text { three-dimensional square rectangular cavity with a } \\
\text { cross-sectional width of } 9.00 \text { in. }(22.9 \mathrm{~cm})(\mathrm{TBV}-238) \text { by } \\
9.00 \mathrm{in} .(22.9 \mathrm{~cm})(\mathrm{TBV}-238) \text { and a length of } 201.1 \text { in. } \\
(510.8 \mathrm{~cm})(\mathrm{TBV}-238) \text {. The canister will not exceed a } \\
\text { weight of (TBD-3765)." }\end{array}$ & $\mathrm{x}$ & & & & LA-R\&P & \\
\hline
\end{tabular}


Table 2. UCF, DHLW, and Naval System Description Document Criteria (Continued)

\begin{tabular}{|c|c|c|c|c|c|c|c|c|c|}
\hline \multicolumn{3}{|c|}{$\begin{array}{c}\text { System Description Document } \\
\text { Criterion Number }\end{array}$} & \multirow[b]{2}{*}{ Criteria Description } & \multicolumn{4}{|c|}{ Design Discipline } & \multirow[b]{2}{*}{$\begin{array}{l}\text { Calculation } \\
\text { Reflecting } \\
\text { Design } \\
\text { Methodology } \\
\text { for SR or LA? }\end{array}$} & \multirow[b]{2}{*}{ Comments } \\
\hline UCF & DHLW & Naval & & 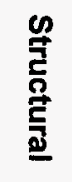 & 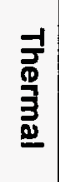 & $\frac{\mathscr{6}}{\frac{\bar{\sigma}}{\alpha}}$ & 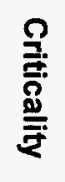 & & \\
\hline N/A & 1.2.1.2 & N/A & $\begin{array}{l}\text { "The disposal container shall accommodate DOE } \\
\text { SNF identified in Table } 2 \text {. (TBV-327) Table } 3 \text { lists } \\
\text { further groupings from Table } 2 \text { used in criticality, } \\
\text { structural, and thermal analyses. Table } 4 \text { lists } \\
\text { further groupings from Table } 2 \text { used in Total System } \\
\text { Performance Assessment (TSPA). The DOE SNF } \\
\text { will arrive at the MGR in disposable canisters of the } \\
\text { sizes and weights identified in Table 5." }\end{array}$ & $\mathrm{X}$ & & & & SR/LA-CA & $\begin{array}{l}\text { Some of the DOE } \\
\text { spent nuclear fuel } \\
\text { waste form will be } \\
\text { addressed for SR, } \\
\text { and the rest for LA- } \\
\text { CA. }\end{array}$ \\
\hline N/A & N/A & 1.2.1.2 & $\begin{array}{l}\text { "The disposal container shall accommodate short } \\
(185.63 \text { in.) and long }(210.63 \text { in. }) \text { naval SNF } \\
\text { canisters made of } 316 \mathrm{~L} \text { stainless steel." }\end{array}$ & $x$ & & & & SR & \\
\hline 1.2.1.3 & 1.2.1.3 & 1.2.1.1 & $\begin{array}{l}\text { "The disposal container/waste package shall be } \\
\text { designed, in conjunction with the Emplacement Drift } \\
\text { System and the natural barrier, such that the } \\
\text { expected annual dose to the average member of the } \\
\text { critical group shall not exceed } 25 \text { mrem total } \\
\text { effective dose equivalent at any time during the first } \\
10,000 \text { years after permanent closure, as a result of } \\
\text { radioactive materials released from the geologic } \\
\text { repository." }\end{array}$ & & & & & N/A & $\begin{array}{l}\text { While the Waste } \\
\text { Package Project } \\
\text { supports the } \\
\text { development of } \\
\text { radionuclide } \\
\text { inventories for Total } \\
\text { System } \\
\text { Performance } \\
\text { Assessment, the } \\
\text { Total System } \\
\text { Performance } \\
\text { Assessment will } \\
\text { show compliance. }\end{array}$ \\
\hline 1.2.1.4 & 1.2.1.4 & N/A & $\begin{array}{l}\text { "The disposal container shall consist of two } \\
\text { cylinders; an inner cylinder that is stainless steel } \\
\text { (alloy } 316 \mathrm{NG} \text { ) with a nominal thickness of } 5 \mathrm{~cm} \text {, and } \\
\text { an outer cylinder that is alloy } 22 \text { material with a } \\
\text { nominal thickness of } 2 \mathrm{~cm} \text {." }\end{array}$ & $x$ & & & & SR & \\
\hline
\end{tabular}


Table 2. UCF, DHLW, and Naval System Description Document Criteria (Continued)

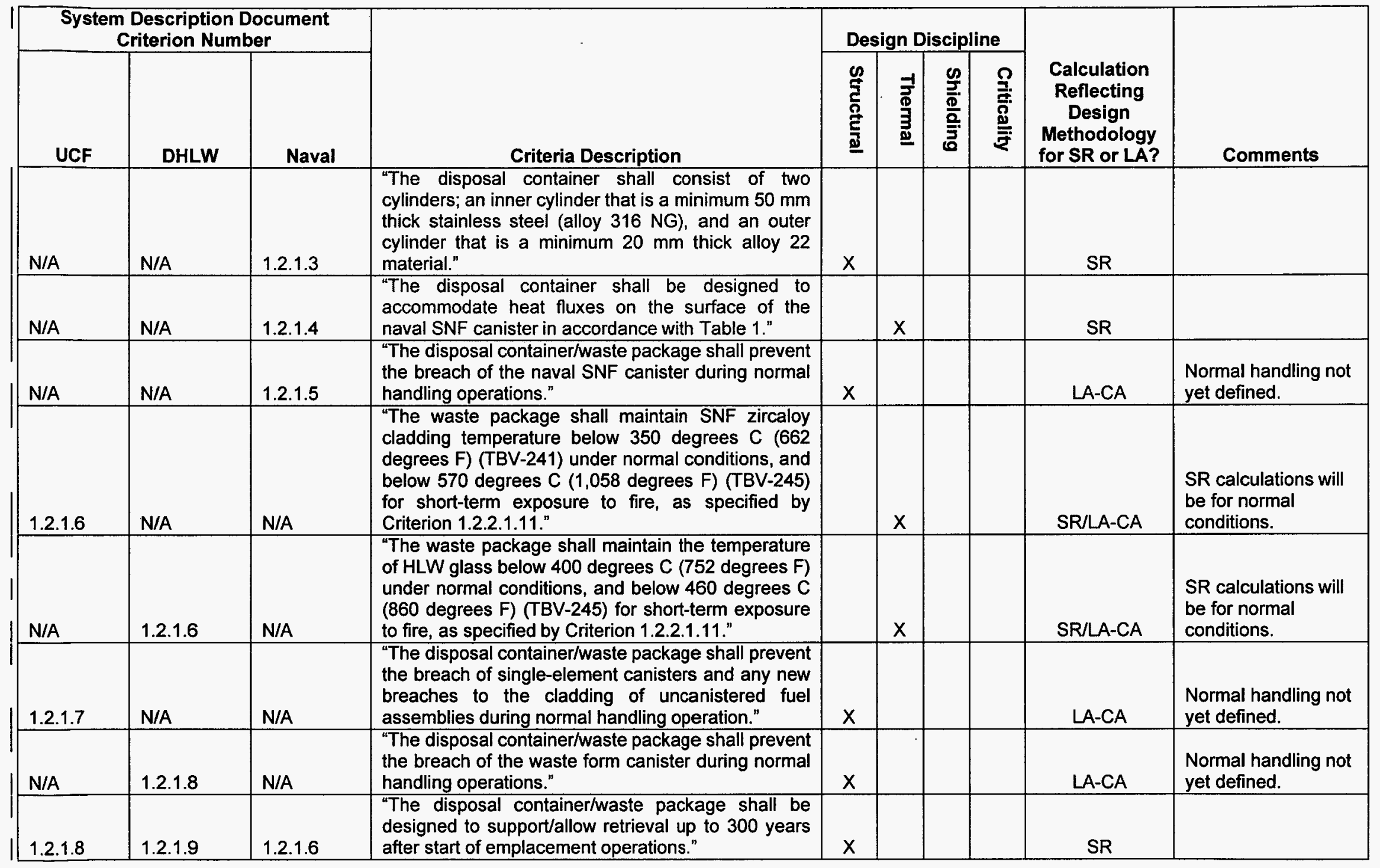


Table 2. UCF, DHLW, and Naval System Description Document Criteria (Continued)

\begin{tabular}{|c|c|c|c|c|c|c|c|c|c|}
\hline \multicolumn{3}{|c|}{$\begin{array}{c}\text { System Description Document } \\
\text { Criterion Number }\end{array}$} & \multirow[b]{2}{*}{ Criteria Description } & \multicolumn{4}{|c|}{ Design Discipline } & \multirow[b]{2}{*}{$\begin{array}{l}\text { Calculation } \\
\text { Reflecting } \\
\text { Design } \\
\text { Methodology } \\
\text { for SR or LA? }\end{array}$} & \multirow[b]{2}{*}{ Comments } \\
\hline UCF & DHLW & Naval & & 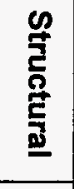 & 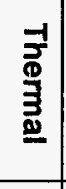 & $\begin{array}{l}\frac{6}{7} \\
\frac{0}{0} \\
\frac{0}{2} \\
0\end{array}$ & 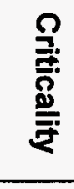 & & \\
\hline 1.2 .1 .9 & 1.2.1.10 & N/A & $\begin{array}{l}\text { "Combined concentrations of } \mathrm{O}_{2}, \mathrm{H}_{2}, \mathrm{H}_{2} \mathrm{O}, \mathrm{CO}_{2} \text { and } \\
\mathrm{CO} \text { within a waste package shall not exceed } 0.25 \\
\text { percent of internal volume (TBV-094), prior to waste } \\
\text { package breach." }\end{array}$ & & & & & LA-R\&P & $\begin{array}{l}\text { It has not been } \\
\text { determined which } \\
\text { discipline will be } \\
\text { responsible for that } \\
\text { criterion. }\end{array}$ \\
\hline 1.2.1.10 & 1.2.1.11 & 1.2.1.7 & $\begin{array}{l}\text { "The disposal container/waste package, excluding } \\
\text { the labels, shall have an external surface finish } \\
\text { Roughness Average of } 250 \mu \text { in }(6.35 \mu \mathrm{m}) \text { or less." }\end{array}$ & $\mathrm{x}$ & & & & LA-R\&P & $\begin{array}{l}\text { Design detail that } \\
\text { need not be } \\
\text { addressed during } \\
\text { LA-CA. }\end{array}$ \\
\hline 1.2.1.11 & 1.2.1.12 & 1.2 .1 .8 & $\begin{array}{l}\text { "The disposal container/waste package shall have } \\
\text { all external surfaces (surfaces exposed to the } \\
\text { external environment after closing and sealing a } \\
\text { disposal container) accessible for visual inspection } \\
\text { and decontamination (e.g., no blind holes)." }\end{array}$ & $\mathrm{x}$ & & & & SR & \\
\hline 1.2.1.12 & 1.2.1.13 & 1.2.1.9 & $\begin{array}{l}\text { "The disposal container/waste package shall have a } \\
\text { label (or other means of identification) with a unique } \\
\text { waste package identifier." }\end{array}$ & $\mathrm{x}$ & & & & LA-R\&P & $\begin{array}{l}\text { Design detail that } \\
\text { need not be } \\
\text { addressed during } \\
\text { LA-CA. }\end{array}$ \\
\hline 1.2.1.13 & 1.2.1.14 & 1.2.1.10 & $\begin{array}{l}\text { "All labels (or other means of identification) applied } \\
\text { to the waste package shall not impair the integrity of } \\
\text { the waste package." }\end{array}$ & $\mathrm{x}$ & & & & LA-R\&P & $\begin{array}{l}\text { Design detail that } \\
\text { need not be } \\
\text { addressed during } \\
\text { LA-CA. }\end{array}$ \\
\hline 1.2.1.14 & 1.2.1.15 & 1.2.1.11 & $\begin{array}{l}\text { "All information contained on all labels (or other } \\
\text { means of identification) applied to the disposal } \\
\text { container/waste package shall be legible or read by } \\
\text { remote means until permanent closure of the } \\
\text { repository." }\end{array}$ & $x$ & & & & LA-R\&P & $\begin{array}{l}\text { Design detail that } \\
\text { need not be } \\
\text { addressed during } \\
\text { LA-CA. }\end{array}$ \\
\hline 1.2 .1 .15 & N/A & N/A & $\begin{array}{l}\text { "The disposal container shall accommodate the use } \\
\text { of filler material (TBV-250), such as iron shot or } \\
\text { depleted uranium, added to the interior of the } \\
\text { disposal container." }\end{array}$ & $\mathrm{x}$ & & & & SR & \\
\hline
\end{tabular}


Table 2. UCF, DHLW, and Naval System Description Document Criteria (Continued)

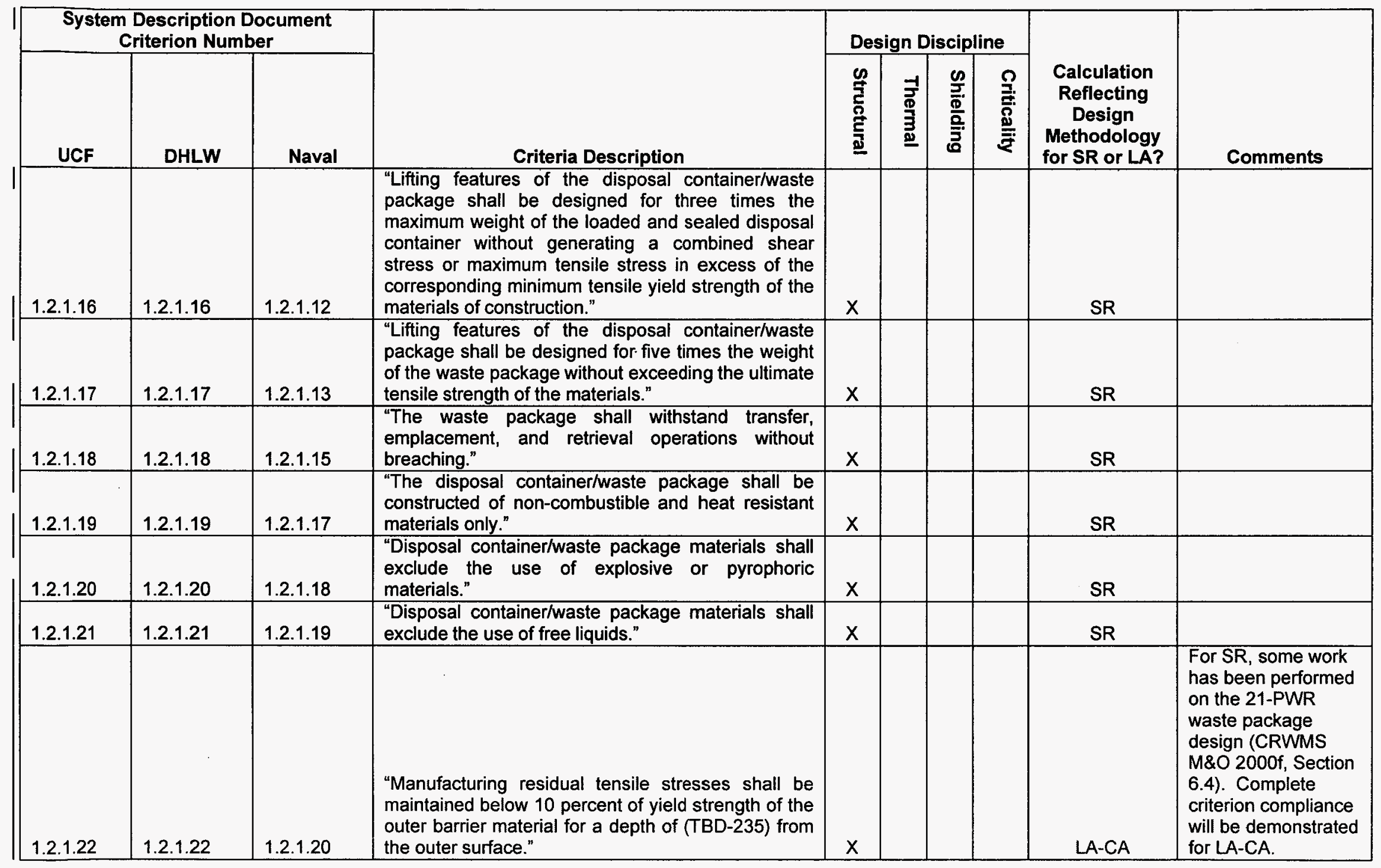


Table 2. UCF, DHLW, and Naval System Description Document Criteria (Continued)

\begin{tabular}{|c|c|c|c|c|c|c|c|c|c|}
\hline \multicolumn{3}{|c|}{$\begin{array}{l}\text { System Description Document } \\
\text { Criterion Number }\end{array}$} & \multirow[b]{2}{*}{ Criteria Description } & \multicolumn{4}{|c|}{ Design Discipline } & \multirow[b]{2}{*}{$\begin{array}{l}\text { Calculation } \\
\text { Reflecting } \\
\text { Design } \\
\text { Methodology } \\
\text { for SR or LA? } \\
\end{array}$} & \multirow[b]{2}{*}{ Comments } \\
\hline UCF & DHLW & Naval & & 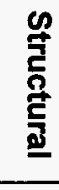 & 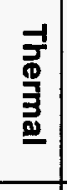 & 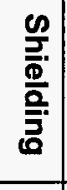 & $\frac{\rho}{\stackrel{\rho}{*}}$ & & \\
\hline 1.2.1.23 & 1.2.1.23 & 1.2.1.21 & $\begin{array}{l}\text { "Static loads in the outer barrier shall not produce } \\
\text { tensile stresses above } 10 \text { percent of yield strength } \\
\text { of the outer barrier material at the interface with the } \\
\text { emplacement pallet." }\end{array}$ & $x$ & & & & LA-CA & $\begin{array}{l}\text { For SR, some work } \\
\text { has been performed } \\
\text { on the naval long } \\
\text { waste package } \\
\text { design (CRWMS } \\
\text { M\&O 2000p). } \\
\text { Complete criterion } \\
\text { compliance will be } \\
\text { demonstrated for LA- } \\
\text { CA. }\end{array}$ \\
\hline 1.2.1.24 & 1.2.1.24 & 1.2.1.22 & $\begin{array}{l}\text { "Tensile stresses in the outer barrier shall be } \\
\text { maintained below yield strength of the outer barrier } \\
\text { material during a seismic event." }\end{array}$ & $\mathrm{x}$ & & & & LA-CA & $\begin{array}{l}\text { Because this } \\
\text { criterion will be } \\
\text { revised in a further } \\
\text { revision of the } \\
\text { system description } \\
\text { documents, } \\
\text { compliance will be } \\
\text { addressed for LA- } \\
\text { CA. }\end{array}$ \\
\hline
\end{tabular}


Table 2. UCF, DHLW, and Naval System Description Document Criteria (Continued)

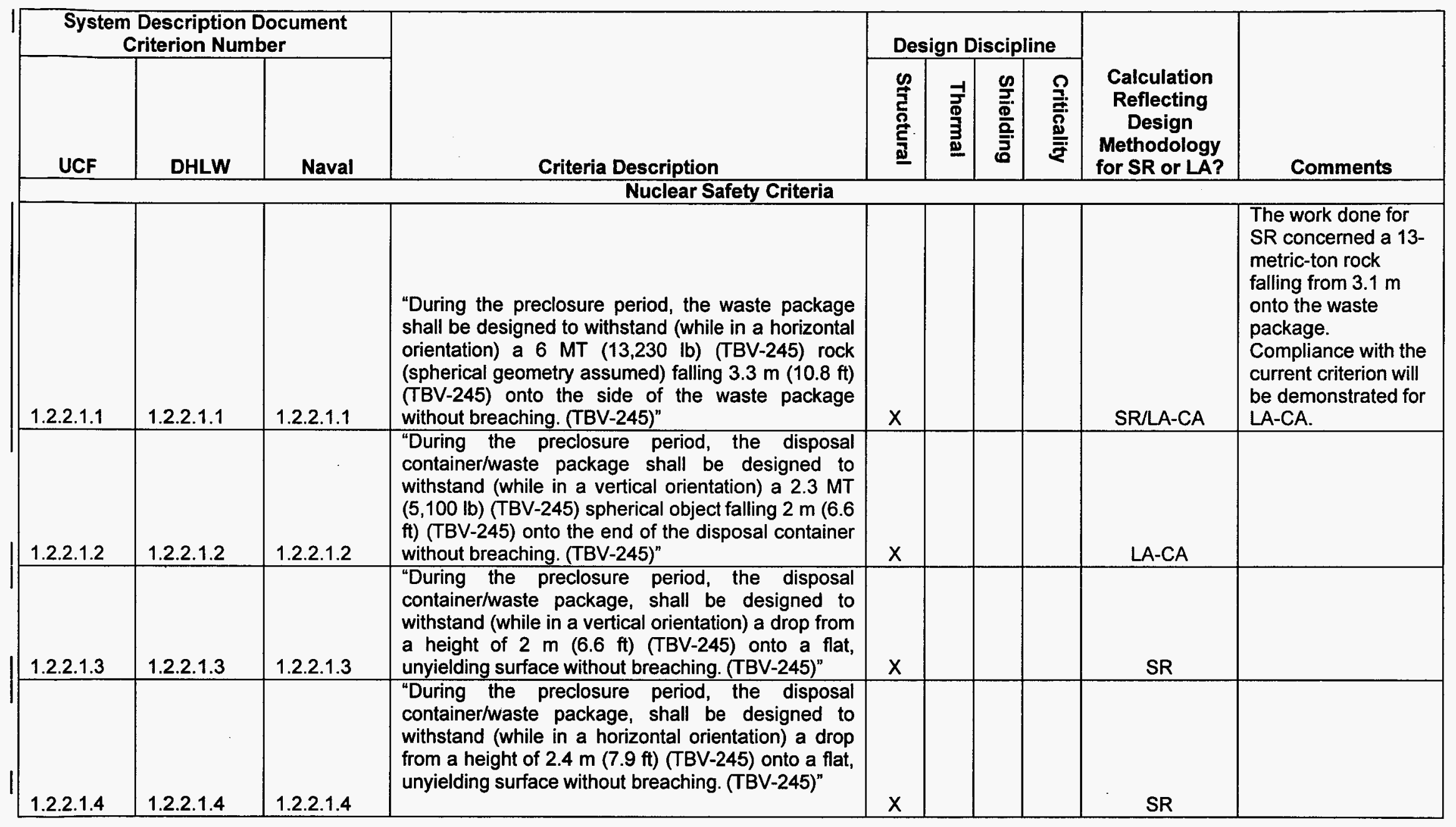


Table 2. UCF, DHLW, and Naval System Description Document Criteria (Continued)

\begin{tabular}{|c|c|c|c|c|c|c|c|c|c|}
\hline \multicolumn{3}{|c|}{$\begin{array}{l}\text { System Description Document } \\
\text { Criterion Number }\end{array}$} & \multirow[b]{2}{*}{ Criteria Description } & \multicolumn{4}{|c|}{ Design Discipline } & \multirow[b]{2}{*}{$\begin{array}{l}\text { Calculation } \\
\text { Reflecting } \\
\text { Design } \\
\text { Methodology } \\
\text { for SR or LA? }\end{array}$} & \multirow[b]{2}{*}{ Comments } \\
\hline UCF & DHLW & Naval & & 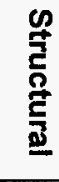 & 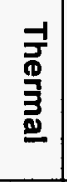 & $\frac{\infty}{\frac{0}{5}}$ & 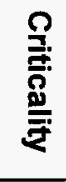 & & \\
\hline 1.2.2.1.5 & 1.2.2.1.5 & 1.2.2.1.5 & $\begin{array}{l}\text { "During the preclosure period, the waste package } \\
\text { shall be designed to withstand (while in a horizontal } \\
\text { orientation) the stress resulting from a drop of the } \\
\text { waste package with the emplacement pallet from a } \\
\text { height of (TBD-235) onto an essentially unyielding } \\
\text { surface without breaching by puncture. (TBV-245)" }\end{array}$ & $x$ & & & & SR/LA-CA & $\begin{array}{l}\text { For SR, the } \\
\text { structural response } \\
\text { of the 44-BWR } \\
\text { waste package was } \\
\text { evaluated. This is } \\
\text { representative of the } \\
\text { work to be } \\
\text { performed for LA- } \\
\text { CA. }\end{array}$ \\
\hline 1.2.2.1.6 & 1.2.2.1.6 & 1.2.2.1.6 & $\begin{array}{l}\text { "During the preclosure period, the waste package } \\
\text { shall be designed to withstand a tip over from a } \\
\text { vertical position with slap down onto a flat, } \\
\text { unyielding surface without breaching. (TBV-245)" }\end{array}$ & $\mathrm{x}$ & & & & SR & \\
\hline 1.2.2.1.7 & 1.2.2.1.7 & 1.2.2.1.7 & $\begin{array}{l}\text { "The waste package shall be designed to withstand } \\
\text { a Frequency Category } 2 \text { Design Basis Earthquake } \\
\text { during the preclosure period (TBV-1246). Both } \\
\text { vibratory ground motion and fault displacement of } \\
\text { the Frequency Category } 2 \text { Design Basis Earthquake } \\
\text { must be considered, taking credit, as appropriate for } \\
\text { interfacing systems that alter or mitigate the effect of } \\
\text { the design basis earthquake on the waste package. } \\
\text { (TBV-245)" }\end{array}$ & $\mathrm{x}$ & & & & LA-CA & \\
\hline 1.2.2.1.8 & 1.2.2.1.8 & 1.2.2.1.8 & $\begin{array}{l}\text { "During the preclosure period, the waste package } \\
\text { shall be designed to withstand the impact of a } 0.5 \mathrm{~kg} \\
(1.1 \mathrm{lb})(\mathrm{TBV}-245) \text { missile (modeled as a } 1 \mathrm{~cm} \\
\text { diameter, } 5 \mathrm{~cm} \text { long valve stem) travelling at } 5.7 \mathrm{~m} \\
\text { per second (18.7 ft/sec) (TBV-245) without } \\
\text { breaching. (TBV-245)" }\end{array}$ & $x$ & & & & SR & \\
\hline
\end{tabular}


Table 2. UCF, DHLW, and Naval System Description Document Criteria (Continued)

\begin{tabular}{|c|c|c|c|c|c|c|c|c|c|}
\hline \multicolumn{3}{|c|}{$\begin{array}{l}\text { System Description Document } \\
\text { Criterion Number }\end{array}$} & \multirow[b]{2}{*}{ Criteria Description } & \multicolumn{4}{|c|}{ Design Discipline } & \multirow[b]{2}{*}{$\begin{array}{l}\text { Calculation } \\
\text { Reflecting } \\
\text { Design } \\
\text { Methodology } \\
\text { for SR or LA? }\end{array}$} & \multirow[b]{2}{*}{ Comments } \\
\hline UCF & DHLW & Naval & & 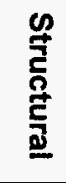 & 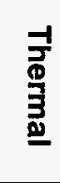 & 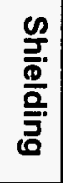 & 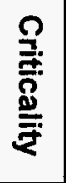 & & \\
\hline 1.2.2.1.9 & 1.2.2.1.9 & 1.2.2.1.9 & $\begin{array}{l}\text { "During the preclosure period, the waste package } \\
\text { shall be designed to withstand, without breaching, } \\
\text { the maximum impact resulting from a transporter } \\
\text { runaway, derailment, and impact at a speed of } 63 \\
\mathrm{~km} / \mathrm{hr}(39 \mathrm{mi} / \mathrm{hr} \text { ) (TBV-245), taking credit as } \\
\text { appropriate for interfacing systems that prevent or } \\
\text { mitigate the impact on the waste package. (TBV- } \\
245 \text { )" }\end{array}$ & $x$ & & & & LA-CA & $\begin{array}{l}\text { Evaluation will } \\
\text { require detailed } \\
\text { transporter design. }\end{array}$ \\
\hline 1.2.2.1.10 & N/A & N/A & $\begin{array}{l}\text { "During the preclosure period, the waste package } \\
\text { shall be designed to withstand a maximum internal } \\
\text { pressure of } 1.01 \mathrm{MPa}(146 \text { psia) (TBV-245) without } \\
\text { breaching. (TBV-245)" }\end{array}$ & $\mathrm{X}$ & & & & SR & \\
\hline N/A & 1.2.2.1.10 & N/A & $\begin{array}{l}\text { "During the preclosure period, the waste package } \\
\text { shall be designed to withstand a maximum internal } \\
\text { pressure of (TBD-235) without breaching. (TBV- } \\
245) \text { " }\end{array}$ & $\mathrm{X}$ & & & & SR & $\begin{array}{l}\text { For SR, this criterion } \\
\text { is evaluated based } \\
\text { on pressures in } \\
\text { accordance with } \\
\text { UCF 1.2.2.1.10. }\end{array}$ \\
\hline N/A & N/A & 1.2.2.1.10 & $\begin{array}{l}\text { "During the preclosure period, the waste package } \\
\text { shall be designed to withstand, without breaching, } \\
\text { the maximum internal pressure of (TBD-235) at an } \\
\text { ambient temperature less than or equal to (TBD- } \\
\text { 235) as generated by (TBD-235). (TBV-245)" }\end{array}$ & $\mathrm{X}$ & & & & SR & $\begin{array}{l}\text { For SR, this criterion } \\
\text { is evaluated based } \\
\text { on pressures in } \\
\text { accordance with } \\
\text { UCF 1.2.2.1.10. }\end{array}$ \\
\hline 1.2.2.1.11 & 1.2.2.1.11 & 1.2.2.1.11 & $\begin{array}{l}\text { "The disposal container/waste package shall be } \\
\text { designed to withstand the hypothetical fire criteria } \\
\text { defined in } 10 \text { CFR } 71 \text { ("Packaging and } \\
\text { Transportation of Radioactive Materials"), Section } \\
\text { 73(c)(4). (TBV-245)" }\end{array}$ & $X$ & $x$ & & & SR/LA-CA & $\begin{array}{l}\text { Structural analysis } \\
\text { for SR based on } \\
\text { withstanding } \\
\text { maximum waste } \\
\text { package } \\
\text { pressurization and } \\
\text { thermal analysis for } \\
\text { LA-CA. }\end{array}$ \\
\hline
\end{tabular}


Table 2. UCF, DHLW, and Naval System Description Document Criteria (Continued)

\begin{tabular}{|c|c|c|c|c|c|c|c|c|c|}
\hline \multicolumn{3}{|c|}{$\begin{array}{c}\text { System Description Document } \\
\text { Criterion Number } \\
\end{array}$} & \multirow[b]{2}{*}{ Criteria Description } & \multicolumn{4}{|c|}{ Design Discipline } & \multirow[b]{2}{*}{$\begin{array}{l}\text { Calculation } \\
\text { Reflecting } \\
\text { Design } \\
\text { Methodology } \\
\text { for SR or LA? }\end{array}$} & \multirow[b]{2}{*}{ Comments } \\
\hline UCF & DHLW & Naval & & 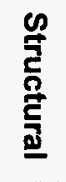 & 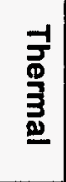 & 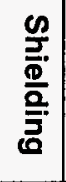 & 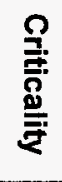 & & \\
\hline 1.2.2.1.12 & 1.2.2.1.12 & 1.2.2.1.12 & $\begin{array}{l}\text { "During the preclosure period, the disposal } \\
\text { container/waste package shall be designed such } \\
\text { that the effective multiplication factor ( } \mathrm{keff} \text { ) is less } \\
\text { than or equal to } 0.95 \text { under assumed accident } \\
\text { conditions considering allowance for the bias in the } \\
\text { method of calculation and the uncertainty in the } \\
\text { experiments used to validate the method of } \\
\text { calculation. (TBV-245)" }\end{array}$ & & & & $\mathrm{x}$ & $\begin{array}{l}\text { SR for UCF } \\
\text { and DHLW } \\
\text { LA-CA for } \\
\text { Naval }\end{array}$ & $\begin{array}{l}\text { A calculation to } \\
\text { show compliance } \\
\text { will be performed by } \\
\text { Naval Reactors for } \\
\text { Naval 1.2.2.1.12, not } \\
\text { the Waste Package } \\
\text { Project. }\end{array}$ \\
\hline 1.2.2.1.13 & 1.2.2.1.13 & N/A & $\begin{array}{l}\text { "During the postclosure period, the waste package } \\
\text { shall be designed such that the total frequency of } \\
\text { criticality occurrence is less than } 1 \text { in } 10,000 \text { years } \\
\text { for all waste packages. (TBV-096)" }\end{array}$ & & & & $\mathrm{x}$ & SR & \\
\hline 1.2.2.1.14 & 1.2.2.1.14 & N/A & $\begin{array}{l}\text { "During the postclosure period, any increase in } \\
\text { radionuclide inventory due to a single criticality } \\
\text { event from fissionable material emplaced in the } \\
\text { waste package shall be less than } 10 \text { percent of the } \\
\text { total radionuclide inventory available for release and } \\
\text { transport for all waste packages to the accessible } \\
\text { environment." }\end{array}$ & & & & & N/A & $\begin{array}{l}\text { This criterion is not } \\
\text { relevant with regard } \\
\text { to the current } \\
\text { methodology, and } \\
\text { therefore will not be } \\
\text { further examined. } \\
\text { Instead, a } \\
\text { consequence } \\
\text { analysis will be } \\
\text { performed for each } \\
\text { possible criticality } \\
\text { event. }\end{array}$ \\
\hline N/A & N/A & 1.2.2.1.13 & $\begin{array}{l}\text { "During the postclosure period, the naval SNF waste } \\
\text { package shall be designed such that nuclear } \\
\text { criticality shall not occur for naval SNF (keff is less } \\
\text { than } 0.95 \text { for all credible configurations)." }\end{array}$ & & & & & $\begin{array}{l}\text { LA-CA for } \\
\text { Naval }\end{array}$ & $\begin{array}{l}\text { A calculation to } \\
\text { show compliance } \\
\text { will be performed by } \\
\text { Naval Reactors, not } \\
\text { the Waste Package } \\
\text { Project. }\end{array}$ \\
\hline
\end{tabular}


Table 2. UCF, DHLW, and Naval System Description Document Criteria (Continued)

\begin{tabular}{|c|c|c|c|c|c|c|c|c|c|}
\hline \multicolumn{3}{|c|}{$\begin{array}{l}\text { System Description Document } \\
\text { Criterion Number }\end{array}$} & \multirow[b]{2}{*}{ Criteria Description } & \multicolumn{4}{|c|}{ Design Discipline } & \multirow[b]{2}{*}{$\begin{array}{l}\text { Calculation } \\
\text { Reflecting } \\
\text { Design } \\
\text { Methodology } \\
\text { for SR or LA? }\end{array}$} & \multirow[b]{2}{*}{ Comments } \\
\hline UCF & DHLW & Naval & & 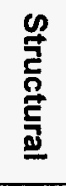 & 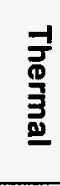 & $\frac{\mathscr{\omega}}{\frac{D}{2}}$ & 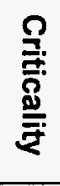 & & \\
\hline \multicolumn{10}{|c|}{ System Environment Criteria } \\
\hline 1.2.3.1 & 1.2.3.1 & 1.2.3.1 & $\begin{array}{l}\text { "The waste package shall meet all performance } \\
\text { requirements during and after exposure to the } \\
\text { emplacement drift external environments identified } \\
\text { in Table } 3 \text { (TBV-4743) (TBD-234) and the } \\
\text { induced/handling external environments identified in } \\
\text { Table } 4 \text { (TBD-276)." }\end{array}$ & $\mathrm{X}$ & $\mathrm{X}$ & & & LA-CA & $\begin{array}{l}\text { Most requirements } \\
\text { are TBD. A } \\
\text { combination of } \\
\text { design evaluations } \\
\text { and Total System } \\
\text { Performance } \\
\text { Assessment will be } \\
\text { required to show } \\
\text { compliance. }\end{array}$ \\
\hline \multicolumn{10}{|c|}{ System Interfacing Criteria } \\
\hline 1.2.4.1 & 1.2.4.1 & N/A & $\begin{array}{l}\text { "Waste package design shall reduce the dose rate } \\
\text { at all external surfaces of a waste package to } 1,450 \\
\text { rem/hr or less. This criterion identifies a disposal } \\
\text { container interface with the Waste } \\
\text { Emplacement/Retrieval System, Disposal Container } \\
\text { Handling System, and Performance Confirmation } \\
\text { Emplacement Drift Monitoring System." }\end{array}$ & & & $\mathrm{X}$ & & SR & $\begin{array}{l}\text { Criterion is not for } \\
\text { waste package } \\
\text { design, but for } \\
\text { interfaces with other } \\
\text { systems. }\end{array}$ \\
\hline N/A & N/A & 1.2.4.1 & $\begin{array}{l}\text { "Disposal container design shall reduce the dose } \\
\text { rate at all external surfaces of a waste package to } \\
\text { (TBD-3764). This criterion identifies a disposal } \\
\text { container interface with the Disposal Container } \\
\text { Handling System, the Waste Emplacement/Retrieval } \\
\text { System, and the Performance Confirmation } \\
\text { Emplacement Drift Monitoring System." }\end{array}$ & & & $x$ & & SR & $\begin{array}{l}\text { Criterion is not for } \\
\text { waste package } \\
\text { design, but for } \\
\text { interfaces with other } \\
\text { systems. }\end{array}$ \\
\hline 1.2.4.2 & 1.2.4.2 & 1.2.4.2 & $\begin{array}{l}\text { "The waste package shall be designed to have a } \\
\text { maximum thermal output of } 11.8 \mathrm{~kW} \text {." }\end{array}$ & & $\mathrm{x}$ & & & SR & \\
\hline 1.2.4.3 & N/A & N/A & $\begin{array}{l}\text { "The quantity of waste forms disposed of in this suite } \\
\text { of disposal containers, in combination with the non- } \\
\text { fuel components and canistered SNF disposal } \\
\text { containers, shall not exceed } 63,000 \text { MTU for the first } \\
\text { repository. This criterion identifies the primary } \\
\text { uncanistered SNF disposal container interface with } \\
\text { the canistered SNF and non-fuel components } \\
\text { disposal containers." }\end{array}$ & & & & & SR & $\begin{array}{l}\text { The waste package } \\
\text { will accept a non- } \\
\text { specified quantity of } \\
\text { these waste forms. } \\
\text { No Waste Package } \\
\text { Project design } \\
\text { discipline is affected } \\
\text { by this criterion. }\end{array}$ \\
\hline
\end{tabular}


Table 2. UCF, DHLW, and Naval System Description Document Criteria (Continued)

\begin{tabular}{|c|c|c|c|c|c|c|c|c|c|}
\hline \multicolumn{3}{|c|}{$\begin{array}{l}\text { System Description Document } \\
\text { Criterion Number }\end{array}$} & & \multicolumn{4}{|c|}{ Design Discipline } & \multirow[b]{2}{*}{$\begin{array}{l}\text { Calculation } \\
\text { Reflecting } \\
\text { Design } \\
\text { Methodology } \\
\text { for SR or LA? }\end{array}$} & \multirow[b]{2}{*}{ Comments } \\
\hline UCF & DHLW & Naval & Criteria Description & 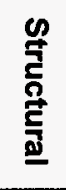 & 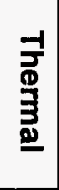 & $\frac{\frac{\infty}{2}}{\frac{\bar{D}}{2}}$ & 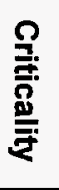 & & \\
\hline$N / A$ & 1.2.4.3 & N/A & $\begin{array}{l}\text { "The system shall be designed to accommodate } 640 \\
\text { MTU of commercial HLW, } 4,027 \text { MTU of defense } \\
\text { HLW, and, in combination with DOE SNF disposal } \\
\text { containers, not more than } 2,437 \text { MTU of DOE SNF. } \\
\text { This criterion identifies the primary disposal } \\
\text { container interface with the DOE Spent Nuclear Fuel } \\
\text { Disposal Container System." }\end{array}$ & & & & & SR & $\begin{array}{l}\text { The waste package } \\
\text { will accept a non- } \\
\text { specified quantity of } \\
\text { these waste forms. } \\
\text { No Waste Package } \\
\text { Project design } \\
\text { discipline is affected } \\
\text { by this criterion. } \\
\text { Note that in this } \\
\text { criterion, MTU } \\
\text { (metric tons of } \\
\text { uranium) should be } \\
\text { interpreted as MTU } \\
\text { equivalent, with } \\
\text { respect to the } \\
\text { reactor fuel from } \\
\text { which the high-level } \\
\text { waste was obtained. }\end{array}$ \\
\hline $\mathrm{N} / \mathrm{A}$ & $\mathrm{N} / \mathrm{A}$ & 1.2.4.3 & $\begin{array}{l}\text { "The quantity of waste forms disposed of in this suite } \\
\text { of disposal containers shall total approximately } 65 \\
\text { MTHM." }\end{array}$ & & & & & SR & $\begin{array}{l}\text { The waste package } \\
\text { will accept a non- } \\
\text { specified quantity of } \\
\text { these waste forms. } \\
\text { No Waste Package } \\
\text { Project design } \\
\text { discipline is affected } \\
\text { by this criterion. }\end{array}$ \\
\hline 1.2.4.4 & $N / A$ & $N / A$ & $\begin{array}{l}\text { "The disposal container shall be designed to be } \\
\text { loaded and sealed in a vertical orientation. This } \\
\text { criterion identifies the primary disposal container } \\
\text { interface with the Assembly Transfer System and } \\
\text { the Disposal Container Handling System." }\end{array}$ & $x$ & & & & SR & \\
\hline
\end{tabular}


Table 2. UCF, DHLW, and Naval System Description Document Criteria (Continued)

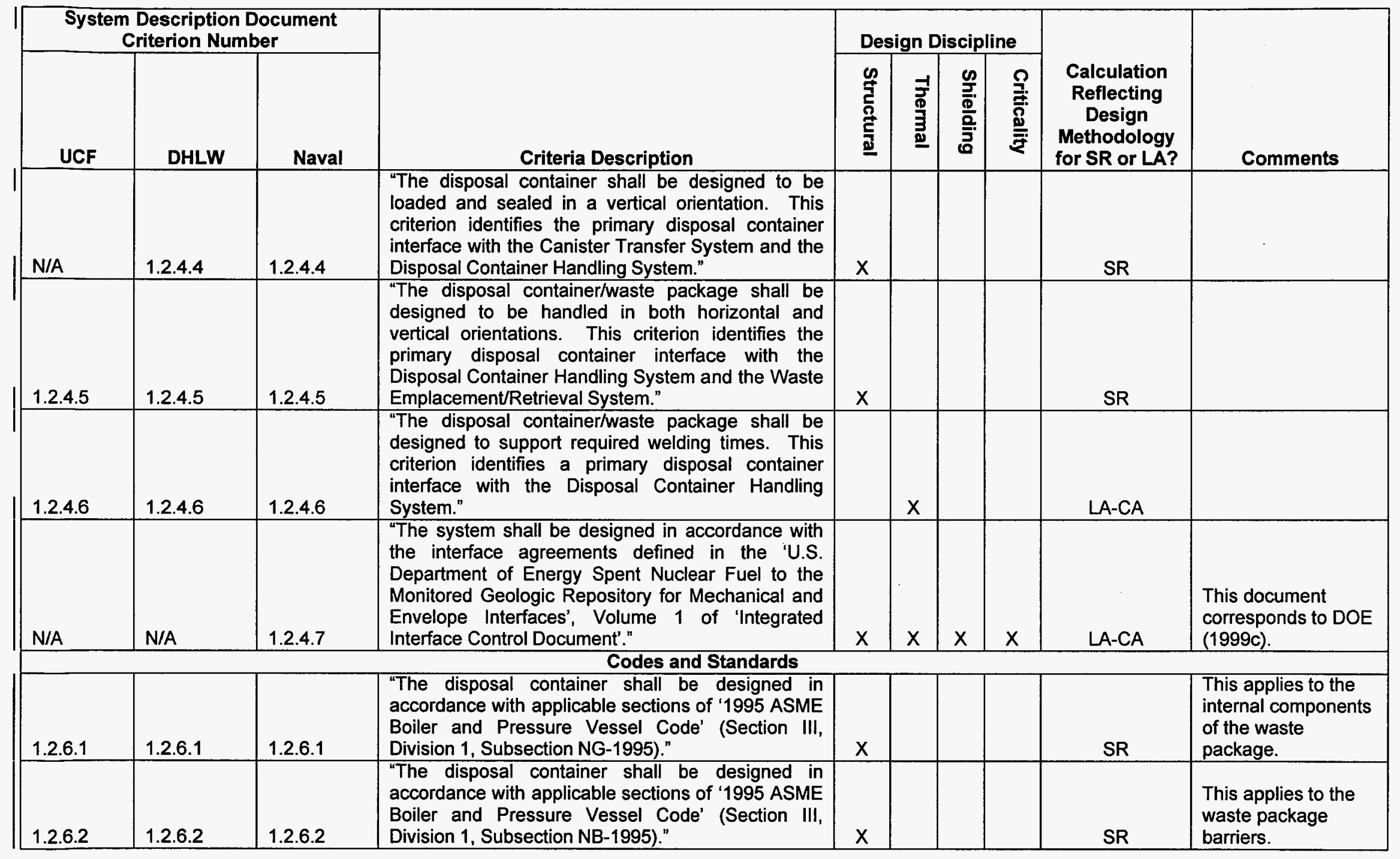


Table 2. UCF, DHLW, and Naval System Description Document Criteria (Continued)

\begin{tabular}{|c|c|c|c|c|c|c|c|c|c|}
\hline \multicolumn{3}{|c|}{$\begin{array}{l}\text { System Description Document } \\
\text { Criterion Number } \\
\end{array}$} & \multirow[b]{2}{*}{ Criteria Description } & \multicolumn{4}{|c|}{ Design Discipline } & \multirow[b]{2}{*}{$\begin{array}{l}\text { Calculation } \\
\text { Reflecting } \\
\text { Design } \\
\text { Methodology } \\
\text { for SR or LA? }\end{array}$} & \multirow[b]{2}{*}{ Comments } \\
\hline UCF & DHLW & Naval & & 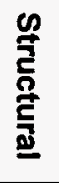 & 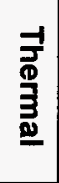 & $\begin{array}{l}\frac{C}{2} \\
\frac{\overline{0}}{2} \\
\frac{2}{6} \\
6\end{array}$ & $\begin{array}{l}\stackrel{\rho}{:} \\
\overline{\overline{\bar{n}}} \\
\frac{\rho}{\overline{\bar{\Sigma}}}\end{array}$ & & \\
\hline 1.2 .6 .3 & 1.2.6.3 & $\mathrm{N} / \mathrm{A}$ & $\begin{array}{l}\text { "The disposal container shall be designed in } \\
\text { accordance with applicable sections of 'Nuclear } \\
\text { Criticality Control of Special Actinide Elements' } \\
\text { (ANSI/ANS-8.15-1981)." }\end{array}$ & & & & $x$ & LA-CA & $\begin{array}{l}\text { As this code was } \\
\text { cited in the Disposal } \\
\text { Criticality Analysis } \\
\text { Methodology Topical } \\
\text { Report (YMP 2000), } \\
\text { SR calculations } \\
\text { based on the topical } \\
\text { report could } \\
\text { demonstrate } \\
\text { compliance. } \\
\text { However, when the } \\
\text { final U.S. Nuclear } \\
\text { Regulatory } \\
\text { Commission (NRC) } \\
\text { Safety Evaluation } \\
\text { Report for the topical } \\
\text { report is complete, it } \\
\text { will supersede this } \\
\text { criterion for LA. }\end{array}$ \\
\hline
\end{tabular}


Table 2. UCF, DHLW, and Naval System Description Document Criteria (Continued)

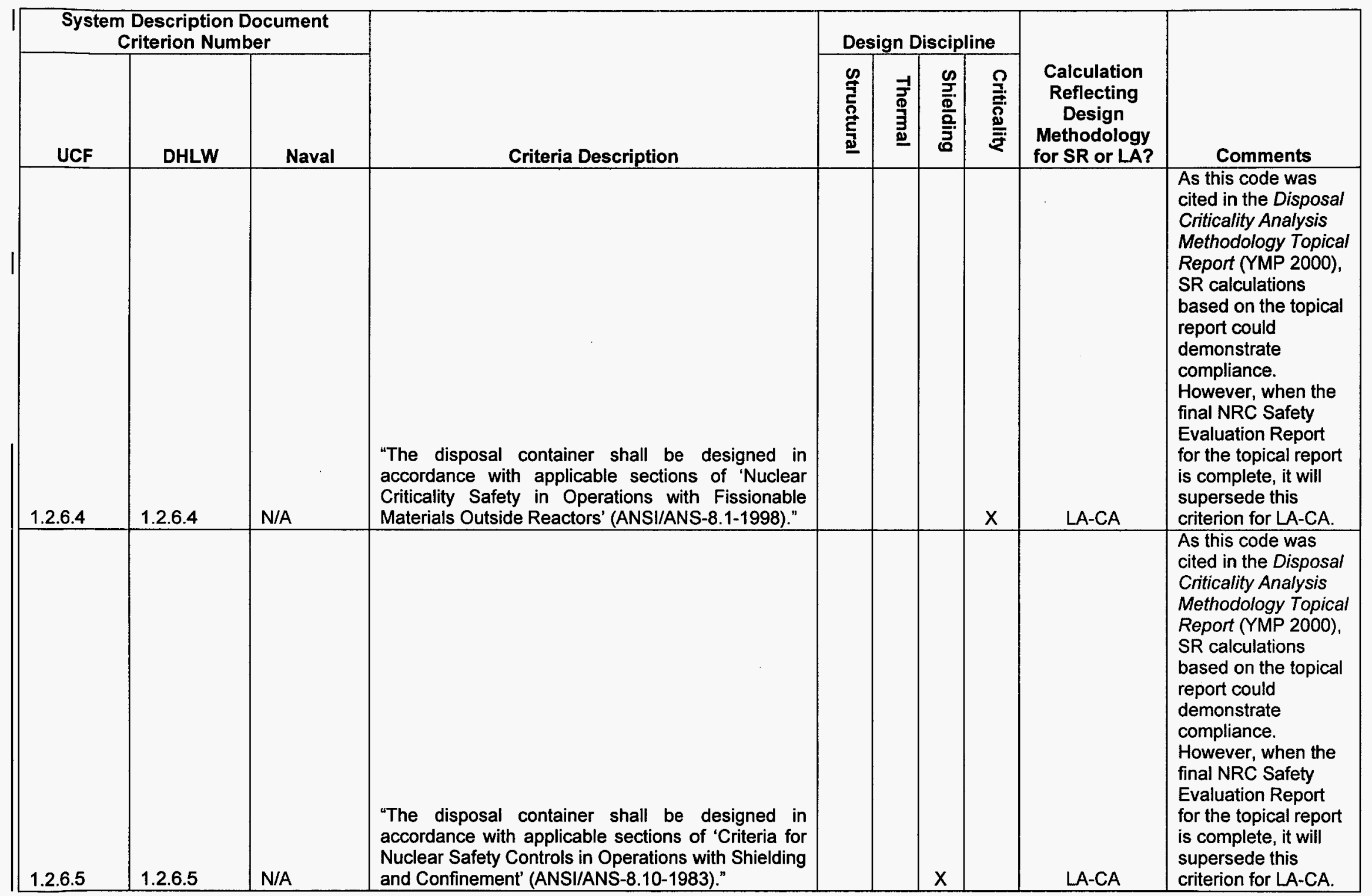


Table 2. UCF, DHLW, and Naval System Description Document Criteria (Continued)

\begin{tabular}{|c|c|c|c|c|c|c|c|c|c|}
\hline \multicolumn{3}{|c|}{$\begin{array}{l}\text { System Description Document } \\
\text { Criterion Number }\end{array}$} & & \multicolumn{4}{|c|}{ Design Discipline } & \multirow[b]{2}{*}{$\begin{array}{l}\text { Calculation } \\
\text { Reflecting } \\
\text { Design } \\
\text { Methodology } \\
\text { for SR or LA? }\end{array}$} & \multirow[b]{2}{*}{ Comments } \\
\hline UCF & DHLW & Naval & Criteria Description & 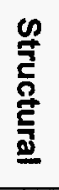 & 吾 & $\frac{\mathscr{6}}{\frac{0}{0}}$ & 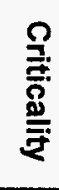 & & \\
\hline 1.2.6.6 & 1.2.6.6 & N/A & $\begin{array}{l}\text { "The disposal container shall be designed in } \\
\text { accordance with applicable sections of 'Criticality } \\
\text { Safety Criteria for the Handling, Storage, and } \\
\text { Transportation of LWR Fuel Outside Reactors' } \\
\text { (ANSI/ANS-8.17-1984)." }\end{array}$ & & & & $x$ & LA-CA & $\begin{array}{l}\text { As this code was } \\
\text { cited in the Disposal } \\
\text { Criticality Analysis } \\
\text { Methodology Topical } \\
\text { Report (YMP 2000), } \\
\text { SR calculations } \\
\text { based on the topical } \\
\text { report could } \\
\text { demonstrate } \\
\text { compliance. } \\
\text { However, when the } \\
\text { final NRC Safety } \\
\text { Evaluation Report } \\
\text { for the topical report } \\
\text { is complete, it will } \\
\text { supersede this } \\
\text { criterion for LA-CA. }\end{array}$ \\
\hline
\end{tabular}


Table 3. Emplacement Drift System Description Document Criteria

\begin{tabular}{|c|c|c|c|c|c|c|c|}
\hline $\begin{array}{l}\text { System Description } \\
\text { Document Criterion } \\
\text { Number }\end{array}$ & \multirow[b]{2}{*}{ Criteria Description } & \multicolumn{4}{|c|}{ Design Discipline } & \multirow[b]{2}{*}{$\begin{array}{l}\text { Calculation } \\
\text { Reflecting } \\
\text { Design } \\
\text { Methodology } \\
\text { for SR or LA? }\end{array}$} & \multirow[b]{2}{*}{ Comments } \\
\hline Drift & & 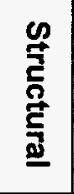 & 縃 & $\begin{array}{l}\frac{\infty}{5} \\
\frac{\bar{\omega}}{2} \\
\frac{2}{5} \\
0\end{array}$ & 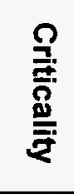 & & \\
\hline \multicolumn{8}{|c|}{$\begin{array}{ll}\text { System Performance Criteria } \\
\end{array}$} \\
\hline 1.2.1.1 & $\begin{array}{l}\text { "The system shall be designed such that when collectively } \\
\text { assessed with the WPs and the natural barrier, the expected } \\
\text { annual dose to the average member of the critical group shall not } \\
\text { exceed } 0.25 \mathrm{mSv}(25 \mathrm{mrem}) \text { total effective dose equivalent at any } \\
\text { time during the first } 10,000 \text { years after permanent closure, as a } \\
\text { result of radioactive materials released from the geologic } \\
\text { repository." }\end{array}$ & & & & & $N / A$ & $\begin{array}{l}\text { Total System } \\
\text { Performance } \\
\text { Assessment to show } \\
\text { compliance. }\end{array}$ \\
\hline 1.2.1.2 & $\begin{array}{l}\text { "The system shall be designed to be capable of accommodating } \\
\text { either } 70,000 \text { or } 97,000 \text { metric tons heavy metal (MTHM) or } \\
\text { equivalent in a single design." }\end{array}$ & & & & & N/A & $\begin{array}{l}\text { As the Waste } \\
\text { Package Project } \\
\text { develops waste } \\
\text { packages to contain } \\
\text { the waste forms } \\
\text { listed, this criterion is } \\
\text { a subsurface layout } \\
\text { issue that the } \\
\text { Subsurface Design } \\
\text { Project will be } \\
\text { required to show } \\
\text { compliance with. }\end{array}$ \\
\hline 1.2.1.3 & $\begin{array}{l}\text { "The system shall be designed to provide for the addition of } \\
\text { features and/or components that enable the system to } \\
\text { accommodate } 115,000 \text { MTHM or equivalent." }\end{array}$ & & & & & N/A & $\begin{array}{l}\text { As the Waste } \\
\text { Package Project } \\
\text { develops waste } \\
\text { packages to contain } \\
\text { the waste forms } \\
\text { listed, this criterion is } \\
\text { a subsurface layout } \\
\text { issue that the } \\
\text { Subsurface Design } \\
\text { Project will be } \\
\text { required to show } \\
\text { compliance with. }\end{array}$ \\
\hline
\end{tabular}


Table 3. Emplacement Drift System Description Document Criteria (Continued)

\begin{tabular}{|c|c|c|c|c|c|c|c|}
\hline \multirow{2}{*}{$\begin{array}{c}\text { System Description } \\
\text { Document Criterion } \\
\text { Number }\end{array}$} & \multirow[b]{2}{*}{ Criteria Description } & \multicolumn{4}{|c|}{ Design Discipline } & \multirow[b]{2}{*}{$\begin{array}{l}\text { Calculation } \\
\text { Reflecting } \\
\text { Design } \\
\text { Methodology } \\
\text { for SR or LA? }\end{array}$} & \multirow[b]{2}{*}{ Comments } \\
\hline & & 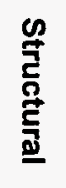 & 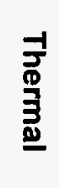 & $\frac{\infty}{\frac{\omega}{2}}$ & 号: & & \\
\hline 1.2.1.4 & $\begin{array}{l}\text { "The system shall limit the temperature of } 50 \text { percent of the pillar } \\
\text { width to } 96 \text { degrees C or less (TBV-4629)." }\end{array}$ & & $\mathrm{X}$ & & & (0. & \\
\hline 1.2.1.5 & $\begin{array}{l}\text { "The system shall be designed to be closed as early as } 30 \text { years } \\
\text { after emplacement of the last WP." }\end{array}$ & & $\mathrm{x}$ & & & SR & \\
\hline 1.2.1.6 & $\begin{array}{l}\text { "The system shall be designed for line loading of WPs within } \\
\text { individual emplacement drifts, defined as a maximum heat load of } \\
1.5 \mathrm{~kW} / \mathrm{m} \text { of emplacement drift, averaged over the entire } \\
\text { emplacement drift at the time of completion of loading of the } \\
\text { emplacement drift." }\end{array}$ & & $\mathrm{X}$ & & & SR & \\
\hline 1.2.1.7 & $\begin{array}{l}\text { "The system shall maintain a 15-m standoff distance between } \\
\text { emplaced WPs and Type I faults, and a 5-m standoff distance } \\
\text { between emplaced WPs and splays associated with Type I faults." }\end{array}$ & & & & & N/A & $\begin{array}{l}\text { Subsurface Design } \\
\text { Project to show } \\
\text { compliance. }\end{array}$ \\
\hline 1.2.1.8 & $\begin{array}{l}\text { "For } 10,000 \text { years, the system shall allow free-liquid-phase water, } \\
\text { from the inflow identified in Table 1, to drain out of emplacement } \\
\text { drifts, via the emplacement drift floor." }\end{array}$ & & & & & N/A & $\begin{array}{l}\text { Subsurface Design } \\
\text { Project to show } \\
\text { compliance. }\end{array}$ \\
\hline 1.2.1.9 & $\begin{array}{l}\text { "The invert structural members shall be composed of carbon } \\
\text { steel." }\end{array}$ & & & & & N/A & $\begin{array}{l}\text { Subsurface Design } \\
\text { Project to show } \\
\text { compliance. }\end{array}$ \\
\hline 1.2.1.10 & $\begin{array}{l}\text { "The invert ballast shall maintain the pH of water within the ballast } \\
\text { to between } 6.7 \text { (TBV-3881) and } 10.2 \text { (TBV-3881) for } 10,000 \\
\text { years." }\end{array}$ & & & & & N/A & $\begin{array}{l}\text { Subsurface Design } \\
\text { Project to show } \\
\text { compliance. }\end{array}$ \\
\hline 1.2.1.11 & "The invert ballast material shall be granular." & & & & & N/A & $\begin{array}{l}\text { Subsurface Design } \\
\text { Project to show } \\
\text { compliance. }\end{array}$ \\
\hline 1.2.1.12 & "The drip shield shall have an operating life of 10,000 years." & & & & & N/A & $\begin{array}{l}\text { Total System } \\
\text { Performance } \\
\text { Assessment to show } \\
\text { compliance. }\end{array}$ \\
\hline 1.2.1.13 & $\begin{array}{l}\text { "The drip shield shall divert water dripping into the emplacement } \\
\text { drift around the WP and to the drift floor." }\end{array}$ & $\mathrm{X}$ & & & & SR & \\
\hline
\end{tabular}


Table 3. Emplacement Drift System Description Document Criteria (Continued)

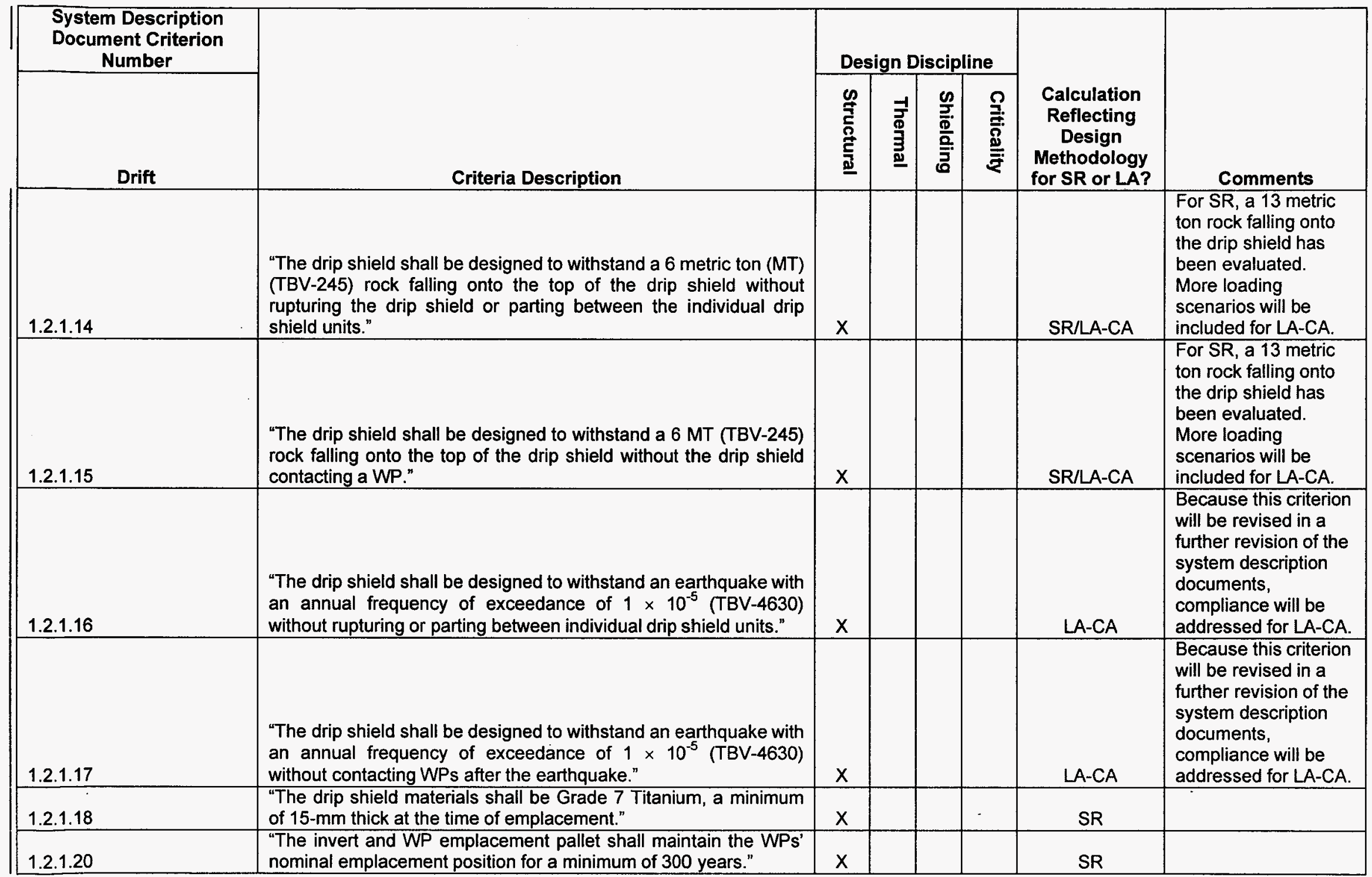


Table 3. Emplacement Drift System Description Document Criteria (Continued)

\begin{tabular}{|c|c|c|c|c|c|c|c|}
\hline $\begin{array}{l}\text { System Description } \\
\text { Document Criterion } \\
\text { Number }\end{array}$ & \multirow[b]{2}{*}{ Criteria Description } & \multicolumn{4}{|c|}{ Design Discipline } & \multirow[b]{2}{*}{$\begin{array}{l}\text { Calculation } \\
\text { Reflecting } \\
\text { Design } \\
\text { Methodology } \\
\text { for SR or LA? }\end{array}$} & \multirow[b]{2}{*}{ Comments } \\
\hline Drift & & 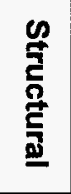 & 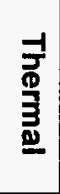 & $\frac{\text { on }}{\frac{\bar{D}}{2}}$ & 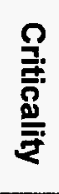 & & \\
\hline 1.2.1.21 & $\begin{array}{l}\text { "The invert and WP emplacement pallet shall maintain the WPs' } \\
\text { nominal horizontal emplacement position for } 10,000 \text { years after } \\
\text { closure." }\end{array}$ & $x$ & & & & LA-CA & \\
\hline 1.2.1.22 & $\begin{array}{l}\text { "The invert and WP emplacement pallet shall provide structural } \\
\text { support for the SSCs as identified in Table 2." }\end{array}$ & $\mathrm{X}$ & & & & SR & \\
\hline 1.2.1.23 & $\begin{array}{l}\text { "Lifting features of the WP Emplacement Pallet shall be designed } \\
\text { for three times the maximum weight of the WP and pallet without } \\
\text { generating a combined shear stress or maximum tensile stress in } \\
\text { excess of the corresponding minimum tensile yield strength of the } \\
\text { materials of construction." }\end{array}$ & $\mathrm{X}$ & & & & SR & \\
\hline 1.2.1.24 & $\begin{array}{l}\text { "Lifting features of the WP Emplacement Pallet shall be designed } \\
\text { for five times the maximum weight of the WP and pallet without } \\
\text { exceeding the ultimate tensile strength of the materials." }\end{array}$ & $\mathrm{X}$ & & & & SR & \\
\hline \multicolumn{8}{|c|}{ Nuclear Safety Criteria } \\
\hline 1.2.2.1.1 & $\begin{array}{l}\text { "The system shall permit all emplacement operations to be } \\
\text { conducted such that WPs are lifted no higher than } 2.4 \text { m (TBV- } \\
\text { 245) above the invert." }\end{array}$ & & & & & N/A & $\begin{array}{l}\text { Subsurface Design } \\
\text { Project to show } \\
\text { compliance. }\end{array}$ \\
\hline 1.2.2.1.2 & $\begin{array}{l}\text { "For } 10,000 \text { years after permanent closure, any increase in } \\
\text { radionuclide inventory due to all criticality events from fissionable } \\
\text { material emplaced in the waste packages shall be less than } 10 \\
\text { percent of the total radionuclide inventory available for release } \\
\text { and transport to the accessible environment. (TBV-096)" }\end{array}$ & & & & & N/A & $\begin{array}{l}\text { Total System } \\
\text { Performance } \\
\text { Assessment to show } \\
\text { compliance. }\end{array}$ \\
\hline \multicolumn{8}{|c|}{ Non-Nuclear Safety Criteria } \\
\hline 1.2.2.2.1 & $\begin{array}{l}\text { "The selection of invert ballast material shall consider the known } \\
\text { health and safety hazards of the materials." }\end{array}$ & & & & & N/A & $\begin{array}{l}\text { Subsurface Design } \\
\text { Project to show } \\
\text { compliance. }\end{array}$ \\
\hline \multicolumn{8}{|c|}{ System Environment Criteria } \\
\hline 1.2.3.1 & $\begin{array}{l}\text { "The system shall limit the emplacement drift wall temperature to } \\
\text { less than } 200 \text { degrees C (TBV-287)." }\end{array}$ & & $\mathrm{X}$ & & & SR & \\
\hline 1.2.3.2 & $\begin{array}{l}\text { "The system shall limit the temperature of zeolite layers located } \\
\text { beneath the emplacement area horizon to less than } 90 \text { degrees } C \\
\text { (TBV-286)." }\end{array}$ & & & & & N/A & $\begin{array}{l}\text { Total System } \\
\text { Performance } \\
\text { Assessment to show } \\
\text { compliance. }\end{array}$ \\
\hline
\end{tabular}


Table 3. Emplacement Drift System Description Document Criteria (Continued)

\begin{tabular}{|c|c|c|c|c|c|c|c|}
\hline $\begin{array}{c}\text { System Description } \\
\text { Document Criterion } \\
\text { Number }\end{array}$ & & \multicolumn{4}{|c|}{ Design Discipline } & \multirow[b]{2}{*}{$\begin{array}{l}\text { Calculation } \\
\text { Reflecting } \\
\text { Design } \\
\text { Methodology } \\
\text { for SR or LA? }\end{array}$} & \multirow[b]{2}{*}{ Comments } \\
\hline Drift & Criteria Description & 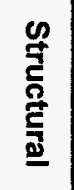 & 素 & $\begin{array}{l}\frac{0}{7} \\
\frac{0}{0} \\
\frac{0}{3} \\
0\end{array}$ & 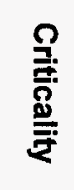 & & \\
\hline 1.2.3.3 & $\begin{array}{l}\text { "The system shall limit the change in temperature, at } 45 \mathrm{~cm} \text { below } \\
\text { the soil surface, to } 2 \text { degrees } C \text { above what the established } \\
\text { naturally occurring pre-emplacement average annual ground } \\
\text { surface temperature is in the area directly above the emplaced } \\
\text { WPs and extending } 500 \mathrm{~m} \text { beyond the edge of the emplaced } \\
\text { WPs. (TBV-617)" }\end{array}$ & & & & & N/A & $\begin{array}{l}\text { Total System } \\
\text { Performance } \\
\text { Assessment to show } \\
\text { compliance. }\end{array}$ \\
\hline 1.2.3.4 & $\begin{array}{l}\text { "The system shall limit the temperature of the PTn geologic unit to } \\
\text { less than } 96 \text { degrees C (TBV-322)." }\end{array}$ & & & & & N/A & $\begin{array}{l}\text { Total System } \\
\text { Performance } \\
\text { Assessment to show } \\
\text { compliance. }\end{array}$ \\
\hline 1.2.3.5 & $\begin{array}{l}\text { "The system shall be designed such that the differential uplift } \\
\text { measured between the top of the TSw } 1 \text { thermomechanical unit } \\
\text { above the repository and the TSw } 1 \text { thermomechanical unit at the } \\
\text { preclosure controlled area boundary is less than } 1 \mathrm{~m} \text { (TBV-618)." }\end{array}$ & & & & & N/A & $\begin{array}{l}\text { Subsurface Design } \\
\text { Project to show } \\
\text { compliance. }\end{array}$ \\
\hline & System Interfacing Criteria & & & & & & \\
\hline 1.2.4.2 & $\begin{array}{l}\text { "The system shall provide physical supports for WPs, as identified } \\
\text { in Tables } 3 \text { and 4." }\end{array}$ & & & & & N/A & $\begin{array}{l}\text { Subsurface Design } \\
\text { Project to show } \\
\text { compliance. }\end{array}$ \\
\hline 1.2.4.3 & $\begin{array}{l}\text { "The system shall accommodate a WP maximum surface dose } \\
\text { rate of } 1410 \mathrm{rad} / \mathrm{hr}(\mathrm{TBV}-248) \text { for an intact WP at the time of } \\
\text { emplacement." }\end{array}$ & & & & & N/A & $\begin{array}{l}\text { The waste package } \\
\text { analysis \& modelling } \\
\text { group and } \\
\text { Subsurface Design } \\
\text { Project to show } \\
\text { compliance. SR } \\
\text { shielding calculations } \\
\text { will present the } \\
\text { design basis dose } \\
\text { rate for the system. }\end{array}$ \\
\hline
\end{tabular}


Table 3. Emplacement Drift System Description Document Criteria (Continued)

\begin{tabular}{|c|c|c|c|c|c|c|c|}
\hline \multirow{2}{*}{$\begin{array}{c}\begin{array}{c}\text { System Description } \\
\text { Document Criterion } \\
\text { Number }\end{array} \\
\\
\\
\text { Drift } \\
\end{array}$} & \multirow[b]{2}{*}{ Criteria Description } & \multicolumn{4}{|c|}{ Design Discipline } & \multirow[b]{2}{*}{$\begin{array}{c}\text { Calculation } \\
\text { Reflecting } \\
\text { Design } \\
\text { Methodology } \\
\text { for SR or LA? }\end{array}$} & \multirow[b]{2}{*}{ Comments } \\
\hline & & 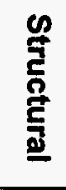 & 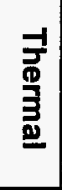 & $\begin{array}{l}\frac{\infty}{\bar{\sigma}} \\
\frac{\bar{\Phi}}{2} \\
\bar{\Xi}\end{array}$ & 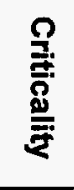 & & \\
\hline 1.2.4.4 & $\begin{array}{l}\text { "The system shall accommodate a maximum WP thermal output } \\
\text { of } 11.8 \mathrm{~kW} \text { at the time of emplacement." }\end{array}$ & & $\mathrm{x}$ & & & SR & \\
\hline 1.2.4.6 & $\begin{array}{l}\text { "The system shall provide for horizontal in-drift emplacement of } \\
\text { WP Emplacement Pallets holding WPs within emplacement drifts } \\
\text { by the Waste Emplacement/Retrieval System." }\end{array}$ & $\mathrm{x}$ & & & & SR & \\
\hline 1.2.4.7 & $\begin{array}{l}\text { "The system shall accommodate a minimum spacing of } 10 \mathrm{~cm} \\
\text { between WPs within individual emplacement drifts." }\end{array}$ & $\mathrm{x}$ & $\mathrm{x}$ & & & SR & \\
\hline 1.2.4.8 & $\begin{array}{l}\text { "The system shall accommodate a nominal spacing of } 81 \mathrm{~m} \\
\text { between individual emplacement drifts." }\end{array}$ & & $\mathrm{x}$ & & & SR & \\
\hline 1.2.4.12 & $\begin{array}{l}\text { "The materials that contact the surface of the WPs, as emplaced } \\
\text { during the preclosure period, shall be the same material as the } \\
\text { WP outer surface." }\end{array}$ & $\mathrm{x}$ & & & & SR & \\
\hline 1.2.4.13 & $\begin{array}{l}\text { "The system shall accommodate an emplacement drift ground } \\
\text { support system composed primarily of carbon steel (steel sets } \\
\text { and/or rock bolts and mesh)." }\end{array}$ & & & & & N/A & $\begin{array}{l}\text { The waste package } \\
\text { analysis \& modelling } \\
\text { group and } \\
\text { Subsurface Design } \\
\text { Project to show } \\
\text { compliance. }\end{array}$ \\
\hline
\end{tabular}


Table 3. Emplacement Drift System Description Document Criteria (Continued)

\begin{tabular}{|c|c|c|c|c|c|c|c|}
\hline \multirow{2}{*}{$\begin{array}{c}\begin{array}{c}\text { System Description } \\
\text { Document Criterion } \\
\text { Number }\end{array} \\
\text { Drift } \\
\end{array}$} & \multirow[b]{2}{*}{ Criteria Description } & \multicolumn{4}{|c|}{ Design Discipline } & \multirow[b]{2}{*}{$\begin{array}{c}\text { Calculation } \\
\text { Reflecting } \\
\text { Design } \\
\text { Methodology } \\
\text { for SR or LA? }\end{array}$} & \multirow[b]{2}{*}{ Comments } \\
\hline & & 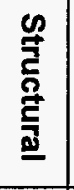 & 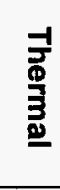 & 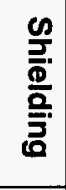 & 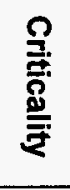 & & \\
\hline 1.2.4.14 & $\begin{array}{l}\text { "The system shall affect the emplacement drift environment such } \\
\text { that WP near field environments of Table } 5 \text { are maintained." }\end{array}$ & & & & & N/A & $\begin{array}{l}\text { Total System } \\
\text { Performance } \\
\text { Assessment to show } \\
\text { compliance. }\end{array}$ \\
\hline 1.2.4.15 & $\begin{array}{l}\text { "The system shall accommodate placement of the invert by the } \\
\text { Subsurface Excavation System." }\end{array}$ & & & & & N/A & $\begin{array}{l}\text { Subsurface Design } \\
\text { Project to show } \\
\text { compliance. }\end{array}$ \\
\hline 1.2.4.16 & $\begin{array}{l}\text { "The system and all WPs emplaced within the system shall be } \\
\text { located at least } 200 \mathrm{~m} \text { below the directly overlying ground surface. } \\
\text { (TBV-619)" }\end{array}$ & & & & & N/A & $\begin{array}{l}\text { Subsurface Design } \\
\text { Project to show } \\
\text { compliance. }\end{array}$ \\
\hline \multicolumn{8}{|c|}{ Codes and Standard Criteria } \\
\hline 1.2 .6 .1 & $\begin{array}{l}\text { "Design of steel SSCs shall be in accordance with 'Manual of } \\
\text { Steel Construction, Allowable Stress Design' or 'Manual of Steel } \\
\text { Construction, Load and Resistance Factor Design'." }\end{array}$ & & & & & N/A & $\begin{array}{l}\text { This criterion refers to } \\
\text { AISC (1995, 1997). } \\
\text { Subsurface Design } \\
\text { Project to show } \\
\text { compliance. }\end{array}$ \\
\hline
\end{tabular}




\section{CONCLUSIONS}

Based on the criteria in Section 6 and the representative waste package designs chosen in Section 5, Tables 4 through 7 list the SR system description document criteria for which compliance is to be demonstrated by the Waste Package Project disciplines for structural, thermal, shielding, and criticality, respectively. In addition, these tables provide information on how compliance has been addressed. Tables 8 and 9 list the LA system description document criteria broken down into two subcategories, respectively: LA-CA and LA-R\&P, with a categorization showing which Waste Package Project discipline team is in charge of providing compliance demonstration.

The following criteria relate to the design geometry or specific design information that can be shown to be compliant by definition of the design.

UCF (CRWMS M\&O 2000r): $\quad 1.2 .1 .1,1.2 .1 .4,1.2 .1 .11,1.2 .1 .19,1.2 .1 .20,1.2 .1 .21$, 1.2.4.2, 1.2.4.3, 1.2.4.4, 1.2.6.1, 1.2.6.2.

DHLW (CRWMS M\&O 2000b): $\quad 1.2 .1 .1,1.2 .1 .2, \quad 1.2 .1 .4,1.2 .1 .12,1.2 .1 .19,1.2 .1 .20$, 1.2.1.21, 1.2.4.2, 1.2.4.3, 1.2.4.4, 1.2.6.1, 1.2.6.2.

Naval (CRWMS M\&O 2000m): $\quad 1.2 .1 .2,1.2 .1 .3,1.2 .1 .8,1.2 .1 .17,1.2 .1 .18,1.2 .1 .19,1.2 .4 .2$, 1.2.4.3, 1.2.4.4, 1.2.6.1, 1.2.6.2.

Drift (CRWMS M\&O 20001): $\quad$ 1.2.1.13, 1.2.1.18, 1.2.4.4, 1.2.4.7, 1.2.4.8, 1.2.4.9, 1.2.4.12. 
Table 4. Structural System Description Document Criteria Addressed for SR

\begin{tabular}{|c|c|c|}
\hline Number & $\begin{array}{c}\text { Criteria } \\
\text { Addressed }\end{array}$ & Comments \\
\hline 1 & $\begin{array}{l}\text { UCF 1.2.1.8 } \\
\text { DHLW 1.2.1.9 } \\
\text { Naval 1.2.1.6 }\end{array}$ & $\begin{array}{l}\text { System description document criterion compliance is addressed in CRWMS } \\
\text { M\&O (2000f, Section 6.2.1.6; } 2000 \text { c, Section 6.2.2.3; 2000e, Section 6.3.1.5). }\end{array}$ \\
\hline 2 & UCF 1.2.1.15 & $\begin{array}{l}\text { System description document criterion compliance is addressed in CRWMS } \\
\text { M\&O (2000f, Section 6.2.1.8). }\end{array}$ \\
\hline 3 & $\begin{array}{l}\text { UCF 1.2.1.16 } \\
\text { DHLW 1.2.1.16 } \\
\text { Naval 1.2.1.12 }\end{array}$ & $\begin{array}{l}\text { System description document criterion compliance is addressed in CRWMS } \\
\text { M\&O (2000f, Section 6.2.1.9; } 2000 \text { c, Sections } 6.2 .2 \text { and } 6.3 ; 2000 \text {, Section } \\
6.3 .1 .7) \text {. }\end{array}$ \\
\hline 4 & $\begin{array}{l}\text { UCF } 1.2 .1 .17 \\
\text { DHLW 1.2.1.17 } \\
\text { Naval 1.2.1.13 }\end{array}$ & $\begin{array}{l}\text { System description document criterion compliance is addressed in CRWMS } \\
\text { M\&O (2000f, Section 6.2.1.10; } 2000 \mathrm{c} \text {, Sections } 6.2 .2 \text { and } 6.3 ; 2000 \text {, Section } \\
6.3 .1 .8 \text { ). }\end{array}$ \\
\hline 5 & $\begin{array}{l}\text { UCF 1.2.1.18 } \\
\text { DHLW 1.2.1.18 } \\
\text { Naval 1.2.1.15 }\end{array}$ & $\begin{array}{l}\text { System description document criterion compliance is addressed in CRWMS } \\
\text { M\&O (2000f, Section 6.2.1.11;2000c, Sections } 6.2 .2 \text { and } 6.3 ; 2000 \text {, Section } \\
6.3 .1 .8 \text { ). }\end{array}$ \\
\hline 6 & $\begin{array}{l}\text { UCF 1.2.2.1.1 } \\
\text { DHLW 1.2.2.1.1 } \\
\text { Naval 1.2.2.1.1 }\end{array}$ & $\begin{array}{l}\text { Compliance with previous UCF system description document criterion (CRWMS } \\
\text { M\&O 1999g, Criterion 1.2.2.1.1) is addressed in CRWMS M\&O (2000f, Section } \\
\text { 6.2.2.1). Complete compliance with the current criteria will be performed for LA- } \\
\text { CA. }\end{array}$ \\
\hline 7 & $\begin{array}{l}\text { UCF 1.2.2.1.3 } \\
\text { DHLW 1.2.2.1.3 } \\
\text { Naval 1.2.2.1.3 }\end{array}$ & $\begin{array}{l}\text { System description document criterion compliance is addressed in CRWMS } \\
\text { M\&O (2000f, Section 6.2.2.2;2000c, Table 15;2000e, Section 6.3.2.3). }\end{array}$ \\
\hline 8 & $\begin{array}{l}\text { UCF } 1.2 .2 .1 .4 \\
\text { DHLW } 1.2 .2 .1 .4 \\
\text { Naval 1.2.2.1.4 }\end{array}$ & $\begin{array}{l}\text { System description document criterion compliance is addressed in CRWMS } \\
\text { M\&O (2000f, Section 6.2.2.3; 2000c, Table } 15 ; 2000 \text { e, Section 6.3.2.4). }\end{array}$ \\
\hline 9 & $\begin{array}{l}\text { UCF } 1.2 \cdot 2 \cdot 1.5 \\
\text { DHLW 1.2.2.1.5 } \\
\text { Naval 1.2.2.1.5 }\end{array}$ & $\begin{array}{l}\text { Compliance with previous UCF system description document criterion (CRWMS } \\
\text { M\&O 1999g, Criterion 1.2.2.1.5) is addressed in CRWMS M\&O (2000f, Section } \\
6.2 .2 .4 \text { ). Complete compliance with the current criteria will be performed for LA- } \\
\text { CA. }\end{array}$ \\
\hline 10 & $\begin{array}{l}\text { UCF 1.2.2.1.6 } \\
\text { DHLW 1.2.2.1.6 } \\
\text { Naval 1.2.2.1.6 }\end{array}$ & $\begin{array}{l}\text { System description document criterion compliance is addressed in CRWMS } \\
\text { M\&O (2000f, Section 6.2.2.5; } 2000 \mathrm{c} \text {, Table } 15 ; 2000 \text { e, Section } 6.3 .2 .5) \text {. }\end{array}$ \\
\hline 11 & $\begin{array}{l}\text { UCF 1.2.2.1.8 } \\
\text { DHLW 1.2.2.1.8 } \\
\text { Naval 1.2.2.1.8 }\end{array}$ & $\begin{array}{l}\text { System description document criterion compliance is addressed in CRWMS } \\
\text { M\&O (2000f, Section 6.2.2.7; 2000c, Sections } 6.2 .2 \text { and } 6.3 ; 2000 \text { e, Section } \\
6.3 .2 .7) \text {. }\end{array}$ \\
\hline 12 & UCF 1.2.2.1.10 & $\begin{array}{l}\text { System description document criterion compliance is addressed in CRWMS } \\
\text { M\&O (2000f, Section 6.2.2.8). }\end{array}$ \\
\hline 13 & DHLW 1.2.2.1.10 & $\begin{array}{l}\text { The perfomance parameter for the waste package design is to be determined } \\
\text { (TBD) and therefore, compliance cannot be demonstrated until the TBD is } \\
\text { resolved. For SR, the system description document criterion is evaluated based } \\
\text { on pressures in accordance with UCF 1.2.2.1.10. }\end{array}$ \\
\hline 14 & Naval 1.2.2.1.10 & $\begin{array}{l}\text { The perfomance parameter for the waste package design is TBD and therefore, } \\
\text { compliance cannot be demonstrated until the TBD is resolved. For SR, the } \\
\text { system description document criterion is evaluated based on pressures in } \\
\text { accordance with UCF } 1.2 .2 .1 .10 \text {. }\end{array}$ \\
\hline 15 & $\begin{array}{l}\text { UCF } 1.2 .2 \cdot 1 \cdot 11 \\
\text { DHLW 1.2.2.1.11 } \\
\text { Naval 1.2.2.1.11 }\end{array}$ & $\begin{array}{l}\text { For SR, system description document criterion compliance is partially addressed } \\
\text { based on work performed for evaluating criteria UCF, DHLW and Naval } \\
1.2 .2 .1 .10 \text {. }\end{array}$ \\
\hline 16 & $\begin{array}{l}\text { UCF 1.2.4.5 } \\
\text { DHLW 1.2.4.5 } \\
\text { Naval 1.2.4.5 }\end{array}$ & $\begin{array}{l}\text { System description document criterion compliance is addressed in CRWMS } \\
\text { M\&O (2000f, Section } 6.2 .3 .5 ; 2000 \mathrm{c} \text {, Section } 6.2 .2 \text { and } 6.3 ; 2000 \mathrm{e} \text {, Section } \\
6.3 .3 .5) \text {. }\end{array}$ \\
\hline 17 & Drift 1.2.1.14 & $\begin{array}{l}\text { For SR, system description document criterion compliance has been partially } \\
\text { addressed (CRWMS M\&O } 2000 \mathrm{~d} \text {, Section 6.1.2.1.5). Complete criterion } \\
\text { compliance will be performed for LA-CA. }\end{array}$ \\
\hline 18 & Drift 1.2.1.15 & $\begin{array}{l}\text { For SR, system description document criterion compliance has been partially } \\
\text { addressed (CRWMS M\&O 2000d, Section 6.1.2.1.6). Complete criterion } \\
\text { compliance will be performed for LA-CA. }\end{array}$ \\
\hline
\end{tabular}


Table 4. Structural System Description Document Criteria Addressed for SR (Continued)

\begin{tabular}{|c|l|l|}
\hline Number & \multicolumn{1}{|c|}{$\begin{array}{c}\text { Criteria } \\
\text { Addressed }\end{array}$} & \multicolumn{1}{c|}{ Comments } \\
\hline 19 & Drift 1.2.1.20 & $\begin{array}{l}\text { System description document criterion compliance is addressed in CRWMS } \\
\text { M\&O (2000d, Section 6.2.2.1.1). }\end{array}$ \\
\hline 20 & Drift 1.2.1.22 & $\begin{array}{l}\text { System description document criterion compliance is addressed in CRWMS } \\
\text { M\&O (2000d, Section 6.2.2.1.3). }\end{array}$ \\
\hline 21 & Drift 1.2.1.23 & $\begin{array}{l}\text { System description document criterion compliance is addressed in CRWMS } \\
\text { M\&O (2000d, Section 6.2.2.7.2). }\end{array}$ \\
\hline 22 & Drift 1.2.1.24 & $\begin{array}{l}\text { System description document criterion compliance is addressed in CRWMS } \\
\text { M\&O (2000d, Section 6.2.2.7.3). }\end{array}$ \\
\hline 23 & Drift 1.2.4.6 & $\begin{array}{l}\text { System description document criterion compliance is addressed in CRWMS } \\
\text { M\&O (2000d, Section 6.2.2.4.2). }\end{array}$ \\
\hline
\end{tabular}

Table 5. Thermal System Description Document Criteria Addressed for SR

\begin{tabular}{|c|c|c|}
\hline Number & $\begin{array}{c}\text { Criteria } \\
\text { Addressed }\end{array}$ & Comments \\
\hline 1 & Naval 1.2.1.4 & $\begin{array}{l}\text { Compliance with previous system description document criterion (CRWMS M\&O } \\
1999 f \text {, Criterion 1.2.1.4) is addressed in CRWMS M\&O (2000e, Section 6.3.1.4). } \\
\text { The justification provided remains relevant for the current criterion. }\end{array}$ \\
\hline 2 & UCF 1.2.1.6 & $\begin{array}{l}\text { System description document criterion compliance is addressed in CRWMS M\&O } \\
\text { (2000f, Section 6.2.1.5). The demonstration of compliance to the temperature } \\
\text { limit for short-term exposure to a fire will not be performed for SR. }\end{array}$ \\
\hline 3 & DHLW 1.2.1.6 & $\begin{array}{l}\text { System description document criterion compliance is addressed in CRWMS M\&O } \\
\text { (2000c, Sections } 6.2 .3 \text { and 6.3). The demonstration of compliance to the } \\
\text { temperature limit for short-term exposure to a fire will not be performed for SR. }\end{array}$ \\
\hline 4 & Drift 1.2.1.4 & $\begin{array}{l}\text { For SR, system description document criterion compliance is partially addressed } \\
\text { in CRWMS M\&O ( } 2000 q) \text {. This calculation is representative of the complemetary } \\
\text { calculations which will demonstrate complete system description document } \\
\text { criterion compliance for LA-CA. }\end{array}$ \\
\hline 5 & Drift 1.2.1.5 & $\begin{array}{l}\text { System description document criterion compliance is addressed in CRWMS M\&O } \\
(2000 \mathrm{j}) \text {. }\end{array}$ \\
\hline 6 & Drift 1.2.1.6 & $\begin{array}{l}\text { Compliance with previous system description document criterion (CRWMS M\&O } \\
2000 \mathrm{k} \text {, Criterion 1.2.1.6) is addressed in CRWMS M\&O (2000d, Section } \\
6.1 .2 .1 .3 \text { ). The justification provided remains relevant for the current criterion. }\end{array}$ \\
\hline 7 & Drift 1.2.3.1 & $\begin{array}{l}\text { Compliance with previous system description document criterion (CRWMS M\&O } \\
2000 \mathrm{k} \text {, Criterion } 1.2 .3 .1) \text { is addressed in CRWMS M\&O (2000d, Section } \\
6.1 .2 .3 .1) \text {. The justification provided remains relevant for the current criterion. }\end{array}$ \\
\hline
\end{tabular}


Table 6. Shielding System Description Document Criteria Addressed for SR

\begin{tabular}{|c|l|l|}
\hline Number & \multicolumn{1}{|c|}{$\begin{array}{c}\text { Criteria } \\
\text { Addressed }\end{array}$} & \multicolumn{1}{c|}{ Comments } \\
\hline & & $\begin{array}{l}\text { CRWMS M\&O (2000g, 2000h) provides the dose rates associated with the 21- } \\
\text { PWR and 44-BWR uncanistered commercial fuel waste package respectively, } \\
\text { showing that the criterion is satisfied. These calculations are representative of } \\
\text { the type of calculations to show compliance with UCF 1.2.4.1 for other } \\
\text { commercial spent nuclear fuel waste package designs. }\end{array}$ \\
\hline 1 & UCF 1.2.4.1 & $\begin{array}{l}\text { CRWMS M\&O (2000i) provides the dose rates associated with the 5-DHLW/DOE } \\
\text { spent nuclear fuel design, showing that the criterion is satisfied. This calculation } \\
\text { is representative of the type of calculations to show compliance with DHLW } \\
1.2 .4 .1 \text { for other DHLW waste package designs. }\end{array}$ \\
\hline 2 & DHLW 1.2.4.1 & $\begin{array}{l}\text { The perfomance parameter for the waste package design is TBD and therefore, } \\
\text { compliance cannot be demonstrated until the TBD is resolved. For SR, CRWMS } \\
\text { M\&O (2000a) provides the dose rates associated with the naval spent nuclear } \\
\text { fuel long design. }\end{array}$ \\
\hline
\end{tabular}

Table 7. Criticality System Description Document Criteria Addressed for SR

\begin{tabular}{|c|c|c|}
\hline Number & $\begin{array}{c}\text { Criteria } \\
\text { Addressed }\end{array}$ & Comments \\
\hline 1 & UCF 1.2.2.1.12 & $\begin{array}{l}\text { Compliance with previous system description document criterion (CRWMS M\&O } \\
1999 \mathrm{~g} \text {, Criterion } 1.2 .2 .1 .12 \text { ) is addressed in CRWMS M\&O (2000f, Section } \\
6.2 .2 .9 \text { ). The justification provided remains relevant for the current criterion. }\end{array}$ \\
\hline 2 & DHLW 1.2.2.1.12 & $\begin{array}{l}\text { Compliance with previous system description document criterion (CRWMS M\&O } \\
1999 \mathrm{~d} \text {, Criterion 1.2.2.1.12) is addressed in CRWMS M\&O (2000c, Sections } 6.2 .5 \\
\text { and 6.3). The justification provided remains relevant for the current criterion. }\end{array}$ \\
\hline 3 & $\begin{array}{l}\text { UCF 1.2.2.1.13 } \\
\text { DHLW 1.2.2.1.13 }\end{array}$ & $\begin{array}{l}\text { Compliance of commercial spent nuclear fuel waste packages with UCF } \\
\text { 1.2.2.1.13 is shown in CRWMS M\&O (2000n, Section 6.2.1). The reasoning } \\
\text { developed in that document also applies to DHLW waste package designs. }\end{array}$ \\
\hline
\end{tabular}

Table 8. System Description Document Criteria to be Addressed for LA-CA

\begin{tabular}{||c|l|l|l|l|}
\cline { 2 - 5 } \multicolumn{1}{c|}{} & \multicolumn{1}{c|}{ Structural } & \multicolumn{1}{c|}{ Thermal } & \multicolumn{1}{c|}{ Shielding } & Criticality \\
\hline UCF & $1.2 .1 .7,1.2 .1 .22$, & $1.2 .1 .6,1.2 .2 .1 .11$, & 1.2 .6 .5 & $1.2 .6 .3,1.2 .6 .4,1.2 .6 .6$ \\
& $1.2 .1 .23,1.2 .1 .24$, & $1.2 .3 .1,1.2 .4 .6$ & & \\
& $1.2 .2 .1 .1,1.2 .2 .1 .2$, & & & \\
& $1.2 .2 .1 .5,1.2 .2 .1 .7$, & & & \\
\hline DHLW & $1.2 .2 .1 .9,1.2 .3 .1$ & & & \\
& $1.2 .1 .2,1.2 .1 .8$, & $1.2 .1 .6,1.2 .2 .1 .11$, & 1.2 .6 .5 & \\
& $1.2 .1 .22,1.2 .1 .23$, & $1.2 .3 .1,1.2 .4 .6$ & & \\
& $1.2 .1 .24,1.2 .2 .1 .1$, & & & \\
& $1.2 .2 .1 .2,1.2 .2 .1 .5$, & & & \\
& $1.2 .2 .1 .7,1.2 .2 .1 .9$, & & & \\
& 1.2 .3 .1 & & \\
\hline Naval & $1.2 .1 .5,1.2 .1 .20$, & $1.2 .2 .1 .11,1.2 .3 .1$, & 1.2 .4 .7 & \\
& $1.2 .1 .21,1.2 .1 .22$, & $1.2 .4 .6,1.2 .4 .7$ & & \\
& $1.2 .2 .1 .1,1.2 .2 .1 .2$, & & & \\
& $1.2 .2 .1 .5,1.2 .2 .1 .7$, & & & \\
& $1.2 .2 .1 .9,1.2 .3 .1$, & & & \\
\hline Drift & 1.2 .4 .7 & & & \\
& $1.2 .1 .14,1.2 .1 .15$, & 1.2 .4 .5 & & \\
& $1.2 .1 .16,1.2 .1 .17$, & & & \\
\hline
\end{tabular}


Table 9. System Description Document Criteria to be Addressed for LA-R\&P

\begin{tabular}{|c|l|l|l|l|}
\cline { 2 - 5 } \multicolumn{1}{c|}{} & \multicolumn{1}{c|}{ Structural } & Thermal & Shielding & Criticality \\
\hline UCF & $1.2 .1 .2,1.2 .1 .10$, & & & \\
& $1.2 .1 .12,1.2 .1 .13$, & & & \\
\hline DHLW & 1.2 .1 .14 & & & \\
& $1.2 .1 .11,1.2 .1 .13$, & & & \\
\hline Naval & $1.2 .1 .14,1.2 .1 .15$ & & & \\
& 1.2 .1 .1 .2 .1 .9$, & & & \\
\hline Drift & 1.2 .4 .11 & & & \\
\hline
\end{tabular}

Compliance of criteria UCF 1.2.1.9 and DHLW 1.2.1.10 will also be addressed for LA-R\&P, but because it has not been determined yet which discipline will be responsible for these criteria, they have not been included in Table 9.

\section{REFERENCES}

\subsection{DOCUMENTS CITED}

CRWMS M\&O 1997. Determination of Waste Package Design Configurations. BBAA0000001717-0200-00017 REV 00. Las Vegas, Nevada: CRWMS M\&O. ACC: MOL.19970805.0310.

CRWMS M\&O 1999a. Analysis of Clearance Envelopes for Emplacement Drift Operating Equipment and Space Envelopes for Test Coupons Within the Emplacement Drift. BCA00000001717-5705-00007 REV 00. Las Vegas, Nevada: CRWMS M\&O. ACC: MOL.19991018.0232.

CRWMS M\&O 1999b. Classification of the MGR Ex-Container System. ANL-XCS-SE-000001 REV 00. Las Vegas, Nevada: CRWMS M\&O. ACC: MOL.19990928.0221.

CRWMS M\&O 1999c. Classification of the MGR Uncanistered Spent Nuclear Fuel Disposal Container System. ANL-UDC-SE-000001 REV 00. Las Vegas, Nevada: CRWMS M\&O. ACC: MOL.19990928.0216.

CRWMS M\&O 1999d. Defense High Level Waste Disposal Container System Description Document. SDD-DDC-SE-000001 REV 00. Las Vegas, Nevada: CRWMS M\&O. ACC: MOL.19991217.0510.

CRWMS M\&O 1999e. License Application Design Selection Feature Report: Aging and Blending. B00000000-01717-2200-00217 REV 00. Las Vegas, Nevada: CRWMS M\&O. ACC: MOL.19990407.0039.

CRWMS M\&O 1999f. Naval Spent Nuclear Fuel Disposal Container System Description Document. SDD-VDC-SE-000001 REV 00. Las Vegas, Nevada: CRWMS M\&O. ACC: MOL.19991217.0511.

CRWMS M\&O 1999g. Uncanistered Spent Nuclear Fuel Disposal Container System 
Description Document. SDD-UDC-SE-000001 REV 00. Las Vegas, Nevada: CRWMS M\&O. ACC: MOL.19991217.0512.

CRWMS M\&O 2000a. Calculation of the Surface Dose Rates for the Single-CRM Naval SNF Waste Package. CAL-VDC-NU-000001 REV 00. Las Vegas, Nevada: CRWMS M\&O. ACC: MOL.20000221.0710.

CRWMS M\&O 2000b. Defense High Level Waste Disposal Container System Description Document. SDD-DDC-SE-000001 REV 01. Las Vegas, Nevada: CRWMS M\&O. ACC: MOL.20000823.0001.

CRWMS M\&O 2000c. Design Analysis for the Defense High-Level Waste Disposal Container. ANL-DDC-ME-000001 REV 00. Las Vegas, Nevada: CRWMS M\&O. ACC:

MOL.20000627.0254.

CRWMS M\&O 2000d. Design Analysis for the Ex-Container Components. ANL-XCS-ME000001 REV 00. Las Vegas, Nevada: CRWMS M\&O. ACC: MOL.20000525.0374.

CRWMS M\&O 2000e. Design Analysis for the Naval SNF Waste Package. ANL-VDC-ME000001 REV 00. Las Vegas, Nevada: CRWMS M\&O . ACC: MOL.20000615.0029.

CRWMS M\&O 2000f. Design Analysis for UCF Waste Packages. ANL-UDC-MD-000001 REV 00. Las Vegas, Nevada: CRWMS M\&O. ACC: MOL.20000526.0336.

CRWMS M\&O 2000g. Dose Rate Calculation for the 21-PWR UCF Waste Package. CALUDC-NU-000002 REV 00. Las Vegas, Nevada: CRWMS M\&O. ACC: MOL.20000223.0507.

CRWMS M\&O 2000h. Dose Rate Calculation for the 44-BWR UCF Waste Package. CALUDC-NU-000003 REV 00. Las Vegas, Nevada: CRWMS M\&O. ACC: MOL.20000223.0506.

CRWMS M\&O 2000i. Dose Rate Calculation for the DHLW/DOE SNF Codisposal Waste Package. CAL-DDC-NU-000001 REV 00. Las Vegas, Nevada: CRWMS M\&O. ACC: MOL.20000223.0505.

CRWMS M\&O 2000j. Drift Scale Thermal Analysis. CAL-WIS-TH-000002 REV 00. Las Vegas, Nevada: CRWMS M\&O. ACC: MOL.20000420.0401.

CRWMS M\&O 2000k. Emplacement Drift System Description Document. SDD-EDS-SE000001 REV 00. Las Vegas, Nevada: CRWMS M\&O. ACC: MOL.20000121.0119.

CRWMS M\&O 20001. Emplacement Drift System Description Document. SDD-EDS-SE000001 REV 01. Las Vegas, Nevada: CRWMS M\&O. ACC: MOL.20000803.0348.

CRWMS M\&O 2000m. Naval Spent Nuclear Fuel Disposal Container System Description Document. SDD-VDC-SE-000001 REV 01. Las Vegas, Nevada: CRWMS M\&O. ACC: MOL.20000817.0544.

CRWMS M\&O 2000n. Probability of Criticality Before 10,000 Years. CAL-EBS-NU-000014 
REV 00. Las Vegas, Nevada: CRWMS M\&O. ACC: MOL.20001107.0303.

CRWMS M\&O 2000o. Technical Work Plan for: Waste Package Design Description for LA. TWP-EBS-MD-000004 REV 00. Las Vegas, Nevada: CRWMS M\&O. ACC: MOL.20001107.0304.

CRWMS M\&O 2000p. Tensile Stresses Developing in an Outer Shell of a Waste Package Mounted on an Emplacement Pallet. CAL-EBS-ME-000004 REV 00. Las Vegas, Nevada: CRWMS M\&O. ACC: MOL.20000207.0715.

CRWMS M\&O 2000q. Two-Dimensional Repository Thermal Design Calculations. CAL-WISTH-000001 REV 00. Las Vegas, Nevada: CRWMS M\&O. ACC: MOL.20000421.0229.

CRWMS M\&O 2000r. Uncanistered Spent Nuclear Fuel Disposal Container System Description Document. SDD-UDC-SE-000001 REV 01. Las Vegas, Nevada: CRWMS M\&O. ACC: MOL.20000822.0004.

CRWMS M\&O 2001. Monitored Geologic Repository Project Description Document. TDRMGR-SE-000004 REV 02 ICN 01. Las Vegas, Nevada: CRWMS M\&O. ACC: MOL.20010212.0296.

Dirkmaat, P.J. 1997. "Response to Repository Environmental Impact Statement (EIS) Data Call (OPE-SFP-97-230)." Memorandum from P.J. Dirkmaat (DOE) to K.J. Skipper, July 10, 1997, with attachment. ACC: MOL.19970725.0067; MOL.19970725.0068.

DOE (U.S. Department of Energy) 1999a. DOE Spent Nuclear Fuel Information in Support of TSPA-SR. DOE/SNF/REP-0047, Rev. 0. [Washington, D.C.]: U.S. Department of Energy, Office of Environmental Management. TIC: 245482.

DOE (U.S. Department of Energy) 1999b. Draft Environmental Impact Statement for a Geologic Repository for the Disposal of Spent Nuclear Fuel and High-Level Radioactive Waste at Yucca Mountain, Nye County, Nevada. DOE/EIS-0250D. Summary, Volumes I and II. Washington, D.C.: U.S. Department of Energy, Office of Civilian Radioactive Waste Management. ACC: MOL.19990816.0240.

DOE (U.S. Department of Energy) 1999c. U.S. Department of Energy Spent Nuclear Fuel to the Monitored Geologic Repository for Mechanical and Envelope Interfaces. Volume 1 of Integrated Interface Control Document. DOE/RW-0511, Rev. 0. Las Vegas, Nevada: U.S. Department of Energy, Office of Civilian Radioactive Waste Management. ACC: MOL.19990428.0236.

DOE (U.S. Department of Energy) 2000. Quality Assurance Requirements and Description. DOE/RW-0333P, Rev. 10. Washington, D.C.: U.S. Department of Energy, Office of Civilian Radioactive Waste Management. ACC: MOL.20000427.0422.

Goff, K.M. 1998. "Revision to Original INEEL Response to Yucca Mountain Site Characterization Office Data Call for High-Level Waste (Ref. Palmer and Benedict to Wichmann, July 2, 1997)." Letter from K.M. Goff (ANL-West) to M.B. Heiser (Lockheed), 
April 15, 1998, with attachment, "Modifications to Yucca Mountain Data Call." ACC:

MOL.19990608.0032.

Picha, K.G., Jr. 1997. "Response to Repository Environmental Impact Statement Data Call for High-Level Waste." Memorandum from K.G. Picha, Jr. (DOE) to W. Dixon (YMSCO), September 5, 1997, with attachments. ACC: MOL.19970917.0273.

Picha, K.G., Jr. 1998. "Clarification of High-Level Waste and Special Performance Assessment Required Data for Repository Environmental Impact Statement." Memorandum from K.G. Picha, Jr. (DOE) to K. Skipper (YMSCO), May 8, 1998, EIS:AR-GEN-35723, with attachments. ACC: MOL.19990610.0297.

YMP (Yucca Mountain Site Characterization Project) 2000. Disposal Criticality Analysis Methodology Topical Report. YMP/TR-004Q, Rev. 01. Las Vegas, Nevada: Yucca Mountain Site Characterization Office. ACC: MOL.20001214.0001.

\subsection{CODES, STANDARDS, REGULATIONS, AND PROCEDURES}

Procedures listed below are retrievable from the Office of Civilian Radioactive Waste Management (OCRWM) Program Documents database contained in Lotus Notes 4.6 and the Bechtel SAIC Company (BSC) INTRANET.

10 CFR 71. 1998. Energy: Packaging and Transportation of Radioactive Material. Readily available.

AISC (American Institute of Steel Construction) 1995. Structural Members, Specification, and Codes. Volume 1 of Manual of Steel Construction, Load \& Resistance Factor Design. 2nd Edition. Chicago, Illinois: American Institute of Steel Construction. TIC: 236850.

AISC (American Institute of Steel Construction) 1997. Manual of Steel Construction, Allowable Stress Design. 9th Edition, 2nd Revision. Chicago, Illinois: American Institute of Steel Construction. TIC: 232994.

ANSI/ANS-8.1-1998. Nuclear Criticality Safety in Operations with Fissionable Material Outside Reactors. La Grange Park, Illinois: American Nuclear Society. TIC: 242363.

ANSI/ANS-8.10-1983. Criteria for Nuclear Criticality Safety Controls in Operations with Shielding and Confinement. La Grange Park, Illinois: American Nuclear Society. TIC: 205015.

ANSI/ANS-8.15-1981. Nuclear Criticality Control of Special Actinide Elements. La Grange Park, Illinois: American Nuclear Society. TIC: 231624.

ANSI/ANS-8.17-1984. Criticality Safety Criteria for the Handling, Storage, and Transportation of LWR Fuel Outside Reactors. La Grange Park, Illinois: American Nuclear Society. TIC: 231625.

AP-3.11Q, Rev. 1, ICN 3, BSCN 1. Technical Reports. Washington, D.C.: U.S. Department of 
Energy, Office of Civilian Radioactive Waste Management.

ASME (American Society of Mechanical Engineers) 1995. 1995 ASME Boiler and Pressure Vessel Code. New York, New York: American Society of Mechanical Engineers. TIC: 245287.

QAP-2-3, Rev. 10, BCSN 2. Classification of Permanent Items. Las Vegas, Nevada: CRWMS $\mathrm{M} \& \mathrm{O}$. 


\section{APPENDIX A}

\section{DETERMINATION OF CODISPOSAL CONFIGURATIONS}

This appendix supports Section 4 by evaluating various waste package codisposal configurations for DOE multi-canister overpacks. In determining the arrangement, this appendix also determines the number of waste packages required for the DOE waste stream. This appendix evaluates the full inventory receipt of DOE waste, which is considered to account for 4141 canisters of DOE spent nuclear fuel canisters, and 22,147 high-level waste canisters (635 containing immobilized plutonium). The breakdown of these figures is shown in Tables A-1 and A-2.

Table A-1. Number of DOE Spent Nuclear Fuel Canisters for Full Inventory of DOE Waste

\begin{tabular}{|c|c|c|}
\hline $\begin{array}{c}\text { DOE Spent Nuclear Fuel } \\
\text { Canister Type }\end{array}$ & Number of Canisters & Reference \\
\hline Short & 1,570 & DOE (1999a, p. 45) \\
\hline Long & $1,874^{\text {a }}$ & DOE $(1999 a$, p. 45) \\
\hline Multi-Canister Overpack & 397 & DOE $(1999 a$, p. 45) \\
\hline Naval Short & 200 & Dirkmaat $(1997$, p. 99) \\
\hline Naval Long & 100 & Dirkmaat $(1997$, p. 99) \\
\hline
\end{tabular}

NOTE: ${ }^{a}$ High-integrity canisters are placed one per long DOE spent nuclear fuel canister, consistent with DOE (1999a, p. 46), which reflects that one or more high-integrity canisters will be placed into a Long DOE spent nuclear fuel canister. The numbers in Table A-1 are consistent with DOE (1999a, Tables 8-2 and 9-2) that reflect one high-integrity canister per waste package.

. Table A-2. Number of High-Level Waste Canisters for Full Inventory of DOE Waste

\begin{tabular}{|c|c|c|c|}
\hline Site & $\begin{array}{c}\text { High-Level Waste } \\
\text { Canister Type }\end{array}$ & Number of Canisters ${ }^{a}$ & Reference \\
\hline Hanford & Long & 14,500 & Picha (1998, Attachment I) \\
\hline $\begin{array}{l}\text { Idaho National Engineering } \\
\text { and Environmental } \\
\text { Laboratory }\end{array}$ & Short & 1,292 & $\begin{array}{l}\text { Picha (1997, p. 9); Goff } \\
(1998, \text { p. 2, Change 1) }\end{array}$ \\
\hline Savannah River Site & Short & $5,343^{c}$ & Picha $(1997$, p. 3) \\
\hline $\begin{array}{l}\text { Savannah River Site, extra } \\
\text { High-Level Waste canisters } \\
\text { created by the incorporation } \\
\text { of immobilized plutonium }\end{array}$ & Short & 77 & $\begin{array}{c}\text { DOE (1999b, Attachment A, } \\
\text { p. A-53) }\end{array}$ \\
\hline $\begin{array}{l}\text { Savannah River Site, } \\
\text { immobilized plutonium } \\
\text { canisters }\end{array}$ & $\begin{array}{l}\text { Short containing } \\
\text { immobilized } \\
\text { plutonium }\end{array}$ & 635 & $\begin{array}{c}\text { DOE (1999b, Attachment A, } \\
\text { p. A-53) }\end{array}$ \\
\hline $\begin{array}{l}\text { West Valley Demonstration } \\
\text { Project }\end{array}$ & Short & 300 & Picha $(1997$, p. 3) \\
\hline
\end{tabular}

NOTES: a Total canister numbers are: 7,012 Short, 635 Short containing immobilized plutonium, and 14,500 long.

b Immobilized plutonium canisters, and extra high-level waste canisters created due to plutonium displacing a portion of the high-level waste in canisters containing the plutonium, are based on disposal of 18 metric tons of plutonium.

c Picha (1997) presents 5,978 short canisters to be produced by Savannah River Site, however due to the inclusion of plutonium, 635 of these canisters are plutonium dispositioned. 
The following constraints are used to determine the potential codisposal configurations for the multi-canister overpacks and DOE waste package numbers:

1) The multi-canister overpack waste package design will contain two multi-canister overpacks in a configuration that provides for an efficient packing density (i.e., minimization of wasted space within a waste package).

2) Outer diameter of the multi-canister overpack waste package cannot exceed the largest diameter for other existing designs (the largest diameter based on current designs is 2.11 $\mathrm{m}$, which is based on the 5-DHLW/DOE SNFdesigns).

3) The canisters containing immobilized plutonium will be placed into the 5-DHLW/DOE SNF Short waste package design with five canisters around the outside basket locations with the center basket location empty (i.e., no DOE spent nuclear fuel canister in the center basket location).

4) DOE waste package designs other than the multi-canister overpack will be as listed in Table 1.

5) Some exceptions to the standard loading of waste packages, as described in Table 1, will include:

a) Packing of one short DOE spent nuclear fuel standard canister with five high-level waste long canisters into the 5-DHLW/DOE SNF Long waste packages. As there are more short DOE spent nuclear fuel standard canisters than can be codisposed with the high-level waste short canisters in the 5-DHLW/DOE SNF Short waste package, some short DOE spent nuclear fuel standard canisters will be disposed of in longer codisposal waste package.

b) Packing of five high-level waste long canisters with no DOE canister into the 5DHLW/DOE Long waste packages. Since there are more high-level waste long canisters than can be codisposed of with DOE spent nuclear fuel, some waste packages will be loaded with only high-level waste long canisters.

Table A-3 presents the multi-canister overpack codisposal options available for consideration after taking the above constraints into consideration.

Table A-3. Potential Multi-Canister Overpack Codisposal Configurations

\begin{tabular}{|c|l|}
\hline Option \# & Configuration \\
\hline 1 & 2 multi-canisters overpacks with 3 short high-level waste canisters \\
\hline 2 & 2 multi-canisters overpacks with 3 long high-level waste canisters \\
\hline 3 & 2 multi-canisters overpacks with 2 short high-level waste canisters \\
\hline 4 & 2 multi-canisters overpacks with 2 long high-level waste canisters \\
\hline
\end{tabular}


For each of the options shown in Table A-3, the number of waste packages required for disposal and the fabrication cost are presented in Tables A-4 through A-7. The fabrication cost information presented is based on the single corrosion-resistant material waste package design with an inner structural cylinder of 316 stainless steel and an outer barrier of corrosion-resistant alloy 22. Additionally, the cost information is based on the single corrosion-resistant material closure lid design. In evaluating that design for stress-corrosion cracking, it was determined that a second corrosion-resistant material closure lid should be added to the waste package designs. Adding a second corrosion-resistant material closure lid to each design should raise the cost for each design approximately the same. Therefore, the total fabrication costs used here will not reflect the latest waste package design modification. However, the results of this evaluation reflecting the most cost effective multi-canister overpack option will remain valid as it is the delta cost values that are important and not the total cost values.

From the four options presented in Table A-3, Option 4 is the most cost-effective solution for packaging of multi-canister overpacks. Table A-7 will represent the waste package types and numbers to be used for the SR design. 
Table A-4. DOE Waste Package Numbers and Costs for Option 1

\begin{tabular}{|c|c|c|c|}
\hline $\begin{array}{c}\text { Waste Package Design } \\
\text { (waste package loading) }\end{array}$ & $\begin{array}{c}\text { Number of Waste } \\
\text { Packages }\end{array}$ & $\begin{array}{c}\text { Fabrication Cost Per } \\
\text { Waste Package } \\
\text { (1999\$ [in millions]) }\end{array}$ & $\begin{array}{l}\text { Total Fabrication Costs } \\
(1999 \$ \text { [in millions]) }\end{array}$ \\
\hline $\begin{array}{l}\text { 5-DHLW/DOE SNF short } \\
\text { (loading: five short high- } \\
\text { level waste canisters } \\
\text { containing plutonium) }\end{array}$ & 127 & 0.306 & 38.862 \\
\hline $\begin{array}{l}\text { 5-DHLW/DOE SNF short } \\
\text { (loading: five short high- } \\
\text { level waste canisters with } \\
\text { one short DOE spent } \\
\text { nuclear fuel canister) }\end{array}$ & 1,283 & 0.306 & 392.598 \\
\hline $\begin{array}{l}\text { 5-DHLW/DOE SNF long } \\
\text { (loading: five long high- } \\
\text { level waste canisters with } \\
\text { one short DOE spent } \\
\text { nuclear fuel canister) }\end{array}$ & 287 & 0.423 & 121.401 \\
\hline $\begin{array}{l}\text { 5-DHLW/DOE SNF long } \\
\text { (loading: five long high- } \\
\text { level waste canisters with } \\
\text { one long DOE spent } \\
\text { nuclear fuel canister) }\end{array}$ & 1,874 & 0.423 & 792.702 \\
\hline $\begin{array}{l}\text { 5-DHLWIDOE SNF long } \\
\text { (loading: five long high- } \\
\text { level waste canisters with } \\
\text { no DOE spent nuclear fuel } \\
\text { canister) }\end{array}$ & 739 & 0.423 & 312.597 \\
\hline 2-MCO/3-DHLW & 199 & 0.395 & 78.605 \\
\hline Naval SNF short & 200 & 0.392 & 78.400 \\
\hline Naval SNF long & 100 & 0.432 & 43.200 \\
\hline Total & 4,809 & & $1,858.365$ \\
\hline
\end{tabular}


Table A-5. DOE Waste Package Numbers and Costs for Option 2

\begin{tabular}{|c|c|c|c|}
\hline $\begin{array}{l}\text { Waste Package Design } \\
\text { (waste package loading) }\end{array}$ & $\begin{array}{c}\text { Number of Waste } \\
\text { Packages }\end{array}$ & $\begin{array}{c}\text { Fabrication Cost Per } \\
\text { Waste Package } \\
\text { (1999\$ [in millions]) }\end{array}$ & $\begin{array}{l}\text { Total Fabrication Costs } \\
\text { (1999\$ [in millions]) }\end{array}$ \\
\hline $\begin{array}{l}\text { 5-DHLW/DOE SNF short } \\
\text { (loading: five short high- } \\
\text { level waste canisters } \\
\text { containing plutonium) }\end{array}$ & 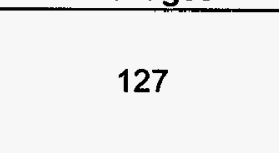 & 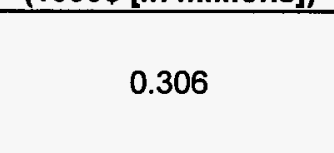 & 1 \\
\hline $\begin{array}{l}\text { 5-DHLW/DOE SNF short } \\
\text { (loading: five short high- } \\
\text { level waste canisters with } \\
\text { one short DOE spent } \\
\text { nuclear fuel canister) }\end{array}$ & 1,403 & 0.306 & 429.318 \\
\hline $\begin{array}{l}\text { 5-DHLW/DOE SNF long } \\
\text { (loading: five long high- } \\
\text { level waste canisters with } \\
\text { one short DOE spent } \\
\text { nuclear fuel canister) }\end{array}$ & 167 & 0.423 & 70.641 \\
\hline $\begin{array}{l}\text { 5-DHLW/DOE SNF long } \\
\text { (loading: five long high- } \\
\text { level waste canisters with } \\
\text { one long DOE spent } \\
\text { nuclear fuel canister) }\end{array}$ & 1,874 & 0.423 & 792.702 \\
\hline $\begin{array}{l}\text { 5-DHLW/DOE SNF long } \\
\text { (loading: five long high- } \\
\text { level waste canisters with } \\
\text { no DOE spent nuclear fuel } \\
\text { canister) }\end{array}$ & 740 & 0.423 & 313.02 \\
\hline 2-MCO/3-DHLW & 199 & 0.423 & 84.177 \\
\hline Naval SNF short & 200 & 0.392 & 78.400 \\
\hline Naval SNF long & 100 & 0.432 & 43.200 \\
\hline Total & 4,810 & & $1,850.320$ \\
\hline
\end{tabular}


Table A-6. DOE Waste Package Numbers and Costs for Option 3

\begin{tabular}{||l|c|c|c|}
\hline $\begin{array}{l}\text { Waste Package Design } \\
\text { (waste package loading) }\end{array}$ & $\begin{array}{c}\text { Number of Waste } \\
\text { Packages }\end{array}$ & $\begin{array}{c}\text { Fabrication Cost Per } \\
\text { Waste Package } \\
\text { (1999\$ [in millions]) }\end{array}$ & $\begin{array}{c}\text { Total Fabrication Costs } \\
\text { (1999\$ [in millions]) }\end{array}$ \\
\hline $\begin{array}{l}\text { 5-DHLW/DOE SNF short } \\
\text { (loading: five short high- } \\
\text { level waste canisters } \\
\text { containing plutonium) }\end{array}$ & 127 & 0.306 & 38.862 \\
\hline $\begin{array}{l}\text { 5-DHLW/DOE SNF short } \\
\text { (loading: five short high- } \\
\text { level waste canisters with } \\
\text { one short DOE spent } \\
\text { nuclear fuel canister) }\end{array}$ & 1,323 & 0.306 & 404.838 \\
\hline $\begin{array}{l}\text { 5-DHLW/DOE SNF long } \\
\text { (loading: five long high- } \\
\text { level waste canisters with } \\
\text { one short DOE spent } \\
\text { nuclear fuel canister) }\end{array}$ & 247 & 0.423 & 104.481 \\
\hline $\begin{array}{l}\text { 5-DHLW/DOE SNF long } \\
\text { (loading: five long high- } \\
\text { level waste canisters with } \\
\text { one long DOE spent } \\
\text { nuclear fuel canister) }\end{array}$ & 1,874 & & \\
\hline $\begin{array}{l}\text { 5-DHLW/DOE SNF } \\
\text { nuclear fuel long (loading: } \\
\text { five long high-level waste } \\
\text { canisters with no DOE } \\
\text { spent nuclear fuel canister) }\end{array}$ & & 0.423 & 792.702 \\
\hline 2-MCO/2-DHLW & 779 & 0.423 & \\
\hline Naval SNF short & 100 & & 329.517 \\
\hline Naval SNF Long & 4,849 & 0.392 & 78.400 \\
\hline Total & 199 & & $1,853.093$ \\
\hline
\end{tabular}


Table A-7. DOE Waste Package Numbers and Costs for Option 4

\begin{tabular}{|c|c|c|c|}
\hline $\begin{array}{l}\text { Waste Package Design } \\
\text { (waste package loading) }\end{array}$ & $\begin{array}{c}\text { Number of Waste } \\
\text { Packages }\end{array}$ & $\begin{array}{c}\text { Fabrication Cost Per } \\
\text { Waste Package } \\
\text { (1999\$ [in millions]) }\end{array}$ & $\begin{array}{c}\text { Total Fabrication Costs } \\
\text { (1999\$ [in millions]) }\end{array}$ \\
\hline $\begin{array}{l}\text { 5-DHLW/DOE SNF short } \\
\text { (loading: five short high- } \\
\text { level waste canisters } \\
\text { containing plutonium) }\end{array}$ & 127 & 0.306 & 38.862 \\
\hline $\begin{array}{l}\text { 5-DHLW/DOE SNF short } \\
\text { (loading: five short high- } \\
\text { level waste canisters with } \\
\text { one short DOE spent } \\
\text { nuclear fuel canister) }\end{array}$ & 1,403 & 0.306 & 429.318 \\
\hline $\begin{array}{l}\text { 5-DHLWIDOE SNF long } \\
\text { (loading: five long high- } \\
\text { level waste canisters with } \\
\text { one short DOE spent } \\
\text { nuclear fuel canister) }\end{array}$ & 167 & 0.423 & 70.641 \\
\hline $\begin{array}{l}\text { 5-DHLW/DOE SNF long } \\
\text { (loading: five long high- } \\
\text { level waste canisters with } \\
\text { one long DOE spent } \\
\text { nuclear fuel canister) }\end{array}$ & 1,874 & 0.423 & 792.702 \\
\hline $\begin{array}{l}\text { 5-DHLWIDOE SNF long } \\
\text { (loading: five long high- } \\
\text { level waste canisters with } \\
\text { no DOE spent nuclear fuel } \\
\text { canister) }\end{array}$ & 780 & 0.423 & 329.94 \\
\hline $2-\mathrm{MCO} / 2-\mathrm{DHLW}$ & 199 & 0.322 & 64.078 \\
\hline Naval SNF short & 200 & 0.392 & 78.400 \\
\hline Naval SNF long & 100 & 0.432 & 43.200 \\
\hline Total & 4,850 & & $1,847.141$ \\
\hline
\end{tabular}

